\title{
Birds of Lake McLarty Nature Reserve, Western Australia: an internationally important wetland facing an uncertain future
}

Michael D. Craig ${ }^{1,2,}$, Glenn I. Moore ${ }^{3,4}$, Tony Kirkby ${ }^{5}$, Marcus Singor ${ }^{6}$, Bill Russell ${ }^{7}$ and John Graff ${ }^{8}$

${ }^{1}$ Centre of Excellence for Environmental Decisions, School of Biological Sciences, University of Western Australia, Nedlands, Western Australia 6907, Australia.

2 School of Veterinary and Life Sciences, Murdoch University, Murdoch, Western Australia 6150, Australia.

3 Department of Aquatic Zoology, Western Australian Museum, 49 Kew Street, Welshpool, Western Australia 6106, Australia.

${ }^{4}$ School of Biological Sciences, University of Western Australia, Nedlands, Western Australia 6907, Australia.

${ }^{5} 20$ Buckingham Road, Kelmscott, Western Australia 6111, Australia.

6 149a Bishopgate Street, Carlisle, Western Australia 6101, Australia.

722 Lake View Road, Preston Beach, Western Australia 6215, Australia.

810 Melrose Crescent, Menora, Western Australia 6050, Australia.

*Corresponding author: michael.craig@uwa.edu.au

\begin{abstract}
Freshwater wetlands are the most threatened major habitat type globally and freshwater birds are consequently disproportionately threatened among birds worldwide. These facts emphasise the need for obtaining detailed data on the occurrence and abundance of waterbirds against which to compare population trends and management actions designed to maintain populations. In response to this need we present information on the occurrence, seasonality and abundance of waterbirds and landbirds at Lake McLarty Nature Reserve, located approximately $85 \mathrm{~km}$ SSW of Perth, Western Australia. Most of the reserve consists of Lake McLarty, a shallow freshwater lake, with a narrow ( 40 m wide) fringe of riparian paperbarks (Melaleuca spp.) and Flooded Gums (Eucalyptus rudis) along $~ 90 \%$ of the lake's margin. A total of 100 species of waterbird and 78 species of landbird have been recorded at the reserve. Of the landbirds, the reserve provides habitat for one globally threatened species and one globally threatened subspecies as well as a range of species declining regionally. On the basis of its waterbird populations, Lake McLarty qualifies as a wetland of international importance in its own right. Over 20,000 waterbirds have been recorded on the reserve on 19 separate dates between 1996 and 2008. The reserve has also supported $>1 \%$ of the global population of six species and $>1 \%$ of the flyway population of one additional species. Furthermore, the lake has supported numbers exceeding these thresholds on as many as 50 dates, depending on the species, indicating that the reserve consistently supports globally significant populations of most of these species. Despite the importance of the reserve for waterbird populations, it faces serious threats from a variety of factors of which our data indicate that the changed hydroperiod resulting from reduced rainfall and, likely, groundwater extraction from an adjacent residential development, is the most significant. This changed hydroperiod, which means the lake is now normally dry for four to seven months annually, has also resulted in the increased expression of acid sulphate soils and colonisation of the lakebed by terrestrial plants. All of these threats combine to reduce the habitat quality that Lake McLarty provides for waterbirds. There are current plans to return the lake to an earlier hydroperiod, where it dries for between one and three months annually, and the data presented here should provide a robust baseline against which to assess the success of any future management actions.
\end{abstract}

KEYWORDS: waterbird, wetland, landbird, degradation, management, conservation, climate change 


\section{INTRODUCTION}

Wetlands have been degraded and lost at higher rates than any other ecosystem and freshwater ecosystems are particularly threatened and are the most threatened major habitat type globally (Holland et al. 2012). Consequently, freshwater vertebrate species are declining faster than those in either terrestrial or marine realms and freshwater birds are no exception with $55 \%$ of waterbird species declining globally and $17 \%$ threatened with extinction, both percentages higher than those for all birds (Birdlife International 2017). Historically, the main threats to wetlands globally have been the overexploitation of wetland resources including fish, pollution from agricultural and industrial processes, flow modification to provide water for cities and especially crops, invasive species and habitat destruction or degradation (Dudgeon et al. 2006; Laurance et al. 2014). While all of these threats continue to degrade wetlands, recently climate change has become an additional significant threat, changing hydrological regimes and further contributing to the degradation and loss of wetlands (Strayer and Dudgeon 2010). These increasing threats make it critical to improve our knowledge of the populations and ecology of waterbirds and establish baseline data for a range of wetlands in order to more accurately assess the effect of climate change and other threats into the future. In order to provide these baseline data, we provide here a summary of the waterbird and landbird species recorded at Lake McLarty, an internationally significant wetland, in south-western Western Australia, an area that has lost the majority of its wetlands since European settlement and is also suffering a significant reduction in rainfall due to climate change (Cai and Cowan 2006).

Lake McLarty Nature Reserve (3241'14.9"S, $\left.115^{\circ} 42^{\prime} 51.2^{\prime \prime E}\right)$ is a Class A reserve, 219 ha in area located on the eastern side of the Harvey Estuary approximately $85 \mathrm{~km} \mathrm{SSW}$ of Perth in south-western Australia (Figure 1). Most of the reserve consists of Lake McLarty, a shallow lake, with a narrow ( 40 m wide) fringe of riparian paperbarks (Melaleuca spp.) and Flooded Gums (Eucalyptus rudis) covering 90\% of the lake's margin. Lake McLarty is recognised, based primarily on the waterbird populations it supports, as a wetland of national significance in the Directory of Important Wetlands in Australia (Environment Australia 2001), as a Conservation Category Wetland in the Geomorphic Wetlands Swan Coastal Plain dataset and as a Key Biodiversity Area by Birdlife International (Birdlife International 2018). In addition, it is also part of the Peel-Yalgorup system, which is included on the List of Wetlands of International Importance, commonly known as the Ramsar Convention (Ramsar Sites Information Service 2018). Within the Peel-Yalgorup system, which is a complex of wetlands, Lake McLarty lies $\sim 600 \mathrm{~m}$ E of Peel-Harvey Estuary, a shallow saline to hypersaline wetland $\sim 13,600$ ha in area, and $1 \mathrm{~km} \mathrm{~S}$ of Lake Mealup, which is a shallow freshwater wetland, smaller than Lake McLarty at $\sim 90$ ha in area (Department of Environment and Conservation 2008). Fringing riparian vegetation around Lake McLarty is contiguous with remnant native vegetation that extends north $\sim 7.5 \mathrm{~km}$ almost to Point Grey and south $\sim 8.5 \mathrm{~km}$ to the southern end of the Peel-Harvey Estuary, forming a relatively large remnant of native vegetation (Figure 1).

Lake McLarty is a shallow, oval, medium-sized, seasonal freshwater to brackish lake with a gently sloping bottom that covers a maximum area (since 1998) of 209 ha of the reserve. The lake bed comprises a thin layer of silt that develops into a thicker layer (40 $\mathrm{mm}$ maximum) of silty mud at the northern end. This overlays a firm sand with shell fragment substrate (Craig et al. 2001). Lake McLarty is primarily a surface expression of the groundwater, although it does have a small (650 ha) surface water catchment, with water levels rising and falling seasonally, depending on rainfall. Water is fresh when filled in the winter/spring season and gradually becomes more brackish as water levels drop until it

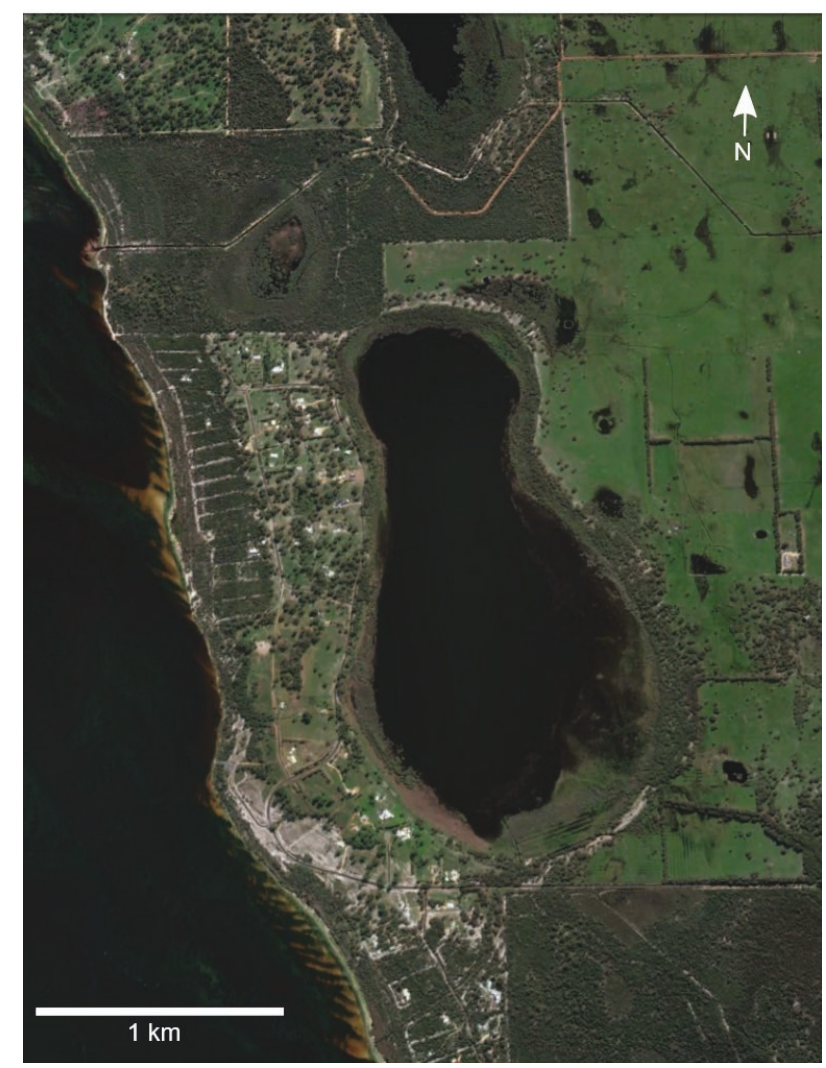

FIGURE 1 Aerial photograph of Lake McLarty (centre) and the surrounding region showing the narrow fringe of riparian vegetation around the lake, Peel-Harvey Estuary to the west, Lake Mealup to the north, native remnant vegetation to the north-west and south, farmland to the east and the residential subdivision along the entire western side of the lake. Photograph was taken on 25 August 2017 when the lake had a water depth of $660 \mathrm{~mm}$ and an area of $160 \mathrm{ha}$. 
reaches a concentration about $1 / 3$ of seawater just before it dries (Muirden 2017). As water levels fall in spring and summer, the lake first dries relatively slowly, from 209 ha at $1.48 \mathrm{~m}$ depth to 175 ha at $0.88 \mathrm{~m}$ and 142 ha at 0.58 $\mathrm{m}$ depth, after which it starts to dry more rapidly from $92 \mathrm{ha}$ at $0.28 \mathrm{~m}$ depth to 61 ha at $0.18 \mathrm{~m}$ and 1.5 ha at $0.06 \mathrm{~m}$ depth (Muirden 2017). Before 2006, the lake typically reached peak water levels around October each year and then dried in early April and was dry for approximately two months. However, since 2006 reductions in rainfall, likely combined with groundwater extraction from the rural residential subdivision, have caused the lake to dry much sooner in late November and early December and remain dry for four to seven months (Muirden 2017).

Aboriginal history on the reserve is essentially unknown. Although Lake McLarty was presumably used as a resource by Bindjareb Nyoongar people over a long period, no sites of significance are known around the lake (Department of Environment and Conservation 2008). European history at Lake McLarty started in 1848 when Arthur Birch established a farm around the lake and commenced clearing of land on the western, southern and eastern sides of the lake to grow wheat and graze cattle, sheep and horses. Clearing continued over the next century until most of the land surrounding Lake McLarty had been converted to farmland, and cattle continued to graze within the reserve up until around 2001 (Department of Environment and Conservation 2008). In 2005, 26 ha adjacent to the western and southwestern boundaries of the reserve were sold as a rural residential subdivision. As of 2017, the subdivision contained 45 dwellings with a requirement to retain all trees and vegetation, although bores have been installed to extract groundwater for residential activities.

Lake McLarty supports diverse and abundant populations of waterbirds (Burbidge and Craig 1996) which results in the lake being popular with birdwatchers, primarily over late spring and summer (November to March) when both the numbers of, and diversity of, waterbirds peaks. Visitation by birdwatchers and other recreational users of the reserve were predicted to increase into the future, both through improved access to the lake from the recently constructed Forrest Highway that runs only $3 \mathrm{~km}$ to the east of the reserve, and the new adjacent rural residential subdivision that will increase in population into the future (Department of Environment and Conservation 2008).

Given these anticipated increased visitation rates, combined with changed climatic and hydrological regimes leading to earlier dying of the lake, there are clear threats to the importance of Lake McLarty for conservation. Hence, we here provide a baseline of the birds recorded at Lake McLarty and the surrounding riparian vegetation within the reserve against which any future change can be compared.

\section{METHODS}

The annotated list presented here is based on two main types of data: (1) complete waterbird counts, where an attempt was made to accurately count every waterbird present; and (2) individual records, which were either counts of (a) only some of the waterbird or landbird species present or (b) records of their presence only. The primary dataset was 130 complete waterbird counts, with incidental landbird records, conducted by Michael Craig and Glenn Moore between 27 December 1985 and 11 February 2018, which included monthly counts from August 2004 to July 2009. This dataset was supplemented by 33 complete waterbird counts by Tony Kirkby, eight of which also had incidental landbird records, and four complete waterbird counts, with incidental landbird records, by Marcus Singor. There were also numerous additional records from Tony Kirkby, Marcus Singor, Bill Russell and John Graff as well as the datasets from the South-West Waterbirds Surveys (Jaensch et al. 1988), Scopewest (Storey et al. 1993) and waterbird and landbird records from John Darnell, including 41 complete waterbird counts. In addition, we searched all issues of Western Australian Bird Notes for records and checked the Birdlife Australia Western Australia Group sightings webpage (http://birdswa.com.au/sightings.htm) for sightings from Lake McLarty. We also downloaded data for Lake McLarty from eBird and vetted those records. We excluded eBird records if the list included species (e.g. White-breasted Robin) that indicated the list had been collected over a much larger area than Lake McLarty Nature Reserve, the list included an otherwise unrecorded species where a similar, common species was unrecorded (e.g. Brown Quail but no Stubble Quail), or the bird was vastly out of range (e.g. Grey Goshawk). We also excluded other records if there were no details of the sighting or who recorded the species (e.g. Restless Flycatcher). This resulted in us retaining a total of 17,745 species records at the reserve, representing more than 2,500,000 individual birds.

Both complete waterbird counts and all records showed temporal biases with relatively few counts or records prior to 1995 (Table 1). Most complete waterbird counts occurred between 1995 and 2009, with relatively even coverage over that 15 year period but relatively few complete counts conducted outside that period. The number of records was highest between 1995 and 2014 but records were not evenly spread over that period with there being approximately twice as many records between 2005 and 2009 than the remaining five-year periods during this time Although we refer to these as 'complete' waterbird counts, it is highly likely that these counts overlooked many individuals of cryptic waterbird species confined to reedbeds (e.g. crakes) although it is also highly likely that most individuals of open water and edges were recorded. Landbirds were recorded incidentally during the course of waterbird surveys, although they were rarely targeted, so landbird numbers recorded would 
have been influenced both by the time of day and time of year of waterbird surveys. Fewer landbirds would have been recorded during surveys at low water levels (because observers would have been more distant from fringing vegetation) or during the middle of the day.

Each waterbird species entry begins with a general comment on the species' abundance. We classified waterbird abundances in nine categories: (1) Abundant - recorded on most surveys, often in very large numbers ( $>1,000$ individuals); (2) Very common recorded on most surveys, often in large numbers $(>100$ individuals); (3) Common - recorded on most surveys in small numbers ( $<100$ individuals); (4) Frequent recorded on 25 to $50 \%$ of surveys; (5) Uncommon - recorded on $<25 \%$ of surveys but sometimes in moderate numbers ( $>10$ individuals); (6) Scarce recorded on $<25 \%$ of surveys and typically in small numbers ( $<10$ individuals); (7) Rare - fewer than 5 records; (8) Very rare - recorded once but could occur again; and (9) Vagrant — recorded once and unlikely to occur again. The proportion of surveys in which a species was recorded relates to only surveys when the species was likely to be present (e.g. excluding surveys when migratory species were absent). We then present information on the seasonal occurrence of the species at Lake McLarty and the months and water depths when peak numbers occurred. This is followed by any relevant comments on the occurrence of the species, e.g. if it has declined or increased in abundance in the last 35 years. A list of the months when the species has been recorded as well as any breeding records and the date of the maximum count and number of birds counted follows. Each landbird species entry also begins with a general comment on the species' abundance but, due to the lack of systematic surveys, these are more an assessment of their relative presence and abundance. For landbirds, we also provide information on the months when species were recorded, as well as any breeding records, but we did not provide maximum counts because the area sampled differed between surveys and so numbers recorded were not directly comparable. Instead, we mention if large numbers of any landbird species were recorded. We obtained global population estimates and population estimates for the East AsianAustralian flyway from the Wetlands International Waterbird Population Estimates online database (http:// wpe.wetlands.org/). For the annotated list, we followed the taxonomy of Johnstone and Darnell (2018) and classify a species as a waterbird if it is dependent on water (Jaensch et al. 1988). Water depths were measured on the permanent depth gauge located at the lowest point of the lake.

\section{RESULTS}

A total of 178 species have been reliably recorded in Lake McLarty Nature Reserve, including 100 waterbird species and 78 landbird species. Among waterbird species, five were considered abundant, seven very
TABLE 1 Variations in the number of complete waterbird counts and number of records over five-year time periods. Note that the number of waterbird counts was much higher from 1995 to 2009 than at other times while the number of records was highest from 2005 to 2009.

\begin{tabular}{lll} 
Period (years) & $\begin{array}{l}\text { Number of total } \\
\text { waterbird counts }\end{array}$ & $\begin{array}{l}\text { Number of } \\
\text { records }\end{array}$ \\
\hline $1980-1984$ & 0 & 159 \\
$1985-1989$ & 3 & 371 \\
$1990-1994$ & 10 & 779 \\
$1995-1999$ & 55 & 2,603 \\
$2000-2004$ & 63 & 3,070 \\
$2005-2009$ & 65 & 5,837 \\
$2010-2014$ & 6 & 3,135 \\
$2015-2018$ & 6 & 1,791 \\
All years & 208 & 17,745 \\
\hline
\end{tabular}

TABLE 2 All 19 dates when the total count of waterbirds exceeded 20,000 individuals, one of the criteria for considering a wetland to be of international importance (Ramsar 2018). Also shown is the water depth (if recorded) on each date.

\begin{tabular}{lll} 
Date & $\begin{array}{l}\text { Water } \\
\text { depth }(\mathrm{mm})\end{array}$ & $\begin{array}{l}\text { Total number } \\
\text { of waterbirds }\end{array}$ \\
\hline 27 December 2002 & 340 & 39,249 \\
29 December 2002 & & 35,852 \\
23 February 1997 & 310 & 34,104 \\
16 January 2003 & 140 & 31,256 \\
31 January 2005 & 280 & 30,479 \\
25 January 1998 & & 30,177 \\
17 February 2005 & 120 & 29,547 \\
20 January 1998 & 300 & 29,110 \\
25 February 1996 & 240 & 26,694 \\
15 December 2002 & & 26,347 \\
5 February 2004 & & 26,020 \\
17 February 1998 & 220 & 23,437 \\
20 January 2004 & 310 & 23,292 \\
1 February 2004 & & 22,739 \\
22 December 2002 & & 21,987 \\
4 February 2005 & & 21,820 \\
26 January 1999 & 125 & 2695 \\
12 January 2008 & 100 & \\
5 January 2003 & & \\
\hline
\end{tabular}


common, 10 common, 10 frequent, 22 uncommon, 20 scarce, 12 rare, eight very rare and six vagrant. Among landbird species, three were considered abundant, 10 very common, 15 common, 10 frequent, 16 uncommon, nine scarce, 10 rare, two very rare and three vagrant.

The highest number of waterbirds recorded at Lake McLarty was 39,249 individuals on 27 December 2002 and 35,852 were still present on 29 December 2002. Between 1996 and 2005, there were a further 17 dates when more than 20,000 waterbirds were recorded, which all occurred between 15 December and 25 February (Table 2). The highest species richness of waterbirds recorded at Lake McLarty was 46 species on 26 December 1997 and 17 January 2009. There were eight further dates, between 1992 and 2004, when 40 or more waterbird species were recorded, which all occurred between 26 December and 29 January (Table 2).

\section{ANNOTATED LIST}

\section{WATERBIRDS}

\section{Black Swan \\ Cygnus atratus (Latham, 1790)}

Very common. Numbers peaked between late October and late April. Abundance varied little in relation to water depth and was only absent when the lake was dry.

Recorded: All months.

Breeding: Many records and probably bred each year. Nests (up to 11) with sitting adults observed in July 1990, July 1997, August 1998, August 2002, August 2007, August 2009, January 2017 and September 2017 and adults with cygnets observed in February 1984, October 1984, October 1986, September 1997, January 1999, October 1999, September 2003, September 2005, November 2006 and October 2013.

Maximum: 2,088 on 19 December 2008.

\section{Freckled Duck}

\section{Stictonetta naevosa (Gould, 1841)}

Scarce visitor in late spring and early summer. All records between late September and late January. Most common when water depth was above $660 \mathrm{~mm}$ and not recorded when water depth was below $420 \mathrm{~mm}$. Most records were of birds among the Paperbarks (Melaleuca raphiophylla) in the south-west corner.

Recorded: January, September to December.

Breeding: November 1997 (unconfirmed).

Maximum: 18 on 31 December 2005.

\section{Australian Shelduck}

\section{Tadorna tadornoides (Jardine and Selby, 1828)}

Abundant. In most years numbers were very high $(>4,500)$ between late October and late November, which likely represents large congregations of moulting individuals, and remained high (up to 2,250) until mid-March after which numbers were lower $(<300)$. Presumably this species uses the lake as a moulting area in October and November. Numbers were highest $(>850)$ when the water depth was above $230 \mathrm{~mm}$ and was only absent when the lake was dry.

Recorded: All months.

Breeding: Pair with young in September 1997, September 2006 and September 2017.

Maximum: 9,432 on 22 October 1997.

\section{Pink-eared Duck}

\section{Malacorhynchus membranaceus (Latham, 1802)}

Irregularly uncommon to common. Most high counts ( $>350)$ were recorded between late December and late February, although up to 889 were present between late October and late December 1997, but the species was very patchy in occurrence and was often absent. For example none were recorded between March 1998 and February 1999. Most common (>400) when water depth was between 220 and $310 \mathrm{~mm}$, but 730 were recorded at a water depth of $960 \mathrm{~mm}$ on 23 November 1997.

Recorded: All months.

Breeding: None recorded.

Maximum: 2,480 on 4 February 1995.

\section{Australian Wood Duck Chenonetta jubata (Latham, 1802)}

Uncommon visitor during most of the year. The sparse records did not correspond with any particular water depth.

Recorded: January, April to December.

Breeding: None recorded.

Maximum: 18 on 9 December 2000.

\section{Mallard}

\section{Anas platyrhynchos Linnaeus 1758}

Rare visitor. The only records were single birds on 20 January 2004, 14 May 2006 and 17 January 2009. A feral species in small numbers on Swan Coastal Plain.

\section{Pacific Black Duck \\ Anas superciliosa Gmelin 1789}

Abundant. Numbers peaked in summer-autumn between late November and early May $(>2,000)$ and when water depth was between 230 and $470 \mathrm{~mm}$ and the species was absent when water depth fell below $110 \mathrm{~mm}$.

Recorded: All months.

Breeding: Several records, probably bred every year. Adults with ducklings seen in August, September and October 1997, September 1998, October 1999 and November 2006.

Maximum: 8,034 on 6 May 2006. 
Australasian Shoveler

Anas rhynchotis Latham, 1802

Common. Numbers peaked $(>380)$ in summer-autumn between late December and mid-April, although up to 460 birds were present in July 2006. Numbers were highest $(>380)$ when the water depth was between 180 and $680 \mathrm{~mm}$.

Recorded: All months.

Breeding: None recorded.

Maximum: 810 on 20 January 1998.

\section{Northern Shoveller \\ Anas clypeata Linnaeus 1758}

Vagrant. One male was seen 16 February 1997 (see Darnell 1997 for more details).

\section{Grey Teal}

\section{Anas gracilis Buller 1869}

Abundant. Numbers were highest $(>2,000)$ between late December and late April, lower at other times of the year. Numbers were highest (often $>6,000$ ) when the water depth was between 125 and $420 \mathrm{~mm}$, no more than 3,100 recorded at other depths.

Recorded: All months.

Breeding: Several records, probably bred every year. Adults with ducklings seen in August 1997, September 1998, September 1999 and October 1999.

Maximum: 18,405 on 27 December 2002.

\section{Chestnut Teal \\ Anas castanea (Eyton, 1838)}

Uncommon. Usually only one or two males present. Counts primarily of males only, but females were presumably equally abundant. Recorded at a wide range of water depth and no obvious relationship between abundance and water depth.

Recorded: All months.

Breeding: None recorded and primarily a nonbreeding visitor to the Swan Coastal Plain.

Maximum: 8 on 1 January 2003.

\section{Hardhead}

\section{Aythya australis (Eyton, 1838)}

Frequent. Occurred primarily between late July and late January with only small numbers $(<50)$ recorded between February and April. Numbers peaked $(>130)$ when water depth was over $650 \mathrm{~mm}$ and not present when the water depth fell below $230 \mathrm{~mm}$.

Recorded: All months.

Breeding: None recorded.

Maximum: 441 on 23 November 1997.

\section{Blue-billed Duck}

\section{Oxyura australis Gould, 1837}

Uncommon. Numbers were highest $(>20)$ between late July and late December with only scattered records of less than 10 birds at other times of the year. Absent when water depth fell below $420 \mathrm{~mm}$.

Recorded: January to May, July to December.

Breeding: Males observed displaying in October 1999.

Maximum: 119 on 29 August 1997.

\section{Musk Duck \\ Biziura lobata (Shaw, 1796)}

Uncommon. Numbers showed no obvious temporal pattern so abundance seems more related to water levels in any particular season than to the month. Generally favours deeper waters as reflected by numbers peaking $(>50)$ when water depth was over $950 \mathrm{~mm}$ and absent when water depths fell below $310 \mathrm{~mm}$.

Recorded: January to April, June to December.

Breeding: Males frequently seen displaying between July and October. Nest with eggs was found in shrubs at the north end of the lake in October 1984 and adults with ducklings seen in November 1997.

Maximum: 200 on 5 November 2000.

\section{Australasian Grebe \\ Tachybaptus novaehollandiae (Stephens, 1826)}

Uncommon, recorded almost year round. Always in smaller numbers than the following species and usually no more than 16 present. No obvious peak in numbers but not observed when the water depth was below 230 $\mathrm{mm}$.

Recorded: January to August, October to December.

Breeding: None recorded.

Maximum: 55 on 21 January 2006.

\section{Hoary headed Grebe \\ Poliocephalus poliocephalus \\ (Jardine and Selby, 1827)}

Common. Numbers peaked (>500) from late September to mid-March and when the water depth was over $620 \mathrm{~mm}$, although the maximum count occurred at a water depth of $300 \mathrm{~mm}$. Not present when the water depth was below $220 \mathrm{~mm}$. This species was unusually abundant from late September 1997 to early February 1998 when between 700 and 3,386 birds were present.

Recorded: All months.

Breeding: None recorded.

Maximum: 3,386 on 20 January 1998.

\section{Great Crested Grebe Podiceps cristatus (Linnaeus 1758)}

Scarce visitor, only recorded from September to February. No obvious peak in abundance during the months it was present and no obvious relationship between abundance and water depth. Up to 28 birds were seen in the early 1980 s but recent sightings were of no more than 8 birds and the most recent sighting was a single bird on 1 February 2009. The lake has probably 
become less attractive for this species as the emergent vegetation has disappeared.

Breeding: Young present on 22 January 1983.

Recorded: January, February, September to December. Maximum: 28 on 22 January 1983.

\section{Australian White Ibis \\ Threskiornis moluccus (Cuvier, 1829)}

Common, although much less so between April and October when fewer than 15 birds were present and apparently absent in June. Numbers peaked $(>50)$ between late November and late February. Not recorded when water depth fell below $240 \mathrm{~mm}$.

Recorded: January to May, July to December.

Breeding: None recorded.

Maximum: 164 on 21 January 2006.

\section{Straw-necked Ibis}

Threskiornis spinicollis (Jameson, 1835)

Frequent, recorded most of the year. Numbers peaked $(>50)$ between October and January although the maximum count was recorded in July. Not recorded when water depth fell below $240 \mathrm{~mm}$. Many records were of birds flying overhead.

Recorded: January to May, July to December.

Breeding: None recorded.

Maximum: 290 on 29 July 2003.

\section{Glossy lbis}

\section{Plegadis falcinellus (Linnaeus, 1766)}

Uncommon visitor, recorded only during spring and summer. Numbers peaked $(>25)$ between late October and early January although there was no obvious relationship with water depth.

Recorded: January to March, September to December.

Breeding: None recorded.

Maximum: 110 on 25 December 2004.

\section{Royal Spoonbill \\ Platalea regia Gould, 1838}

Rare visitor. Only records were of single birds on 26 January 1994 and flying over the lake on 23 February 2014.

\section{Yellow-billed Spoonbill}

\section{Platalea flavipes Gould, 1838}

Common. Numbers peaked $(>30)$ between late January and early May. Most abundant $(>50)$ when water depth was between 240 and $460 \mathrm{~mm}$. Often seen roosting in dead Paperbarks (Melaleuca raphiophylla) at northern end and south-west corner of the lake.

Recorded: All months.

Breeding: None recorded.

Maximum: 200 on 26 January 1994.
Australasian Bittern

\section{Botaurus poiciloptilus (Wagler, 1827)}

Very rare, the only record was of a bird heard calling at the north end of the lake on 17 November 1983.

\section{Nankeen Night Heron}

\section{Nycticorax caledonicus (Gmelin, 1789)}

Uncommon, possibly present year round but only recorded in spring and summer. Probably more common than records suggested due to its nocturnal behaviour. Not recorded when water depth fell below $300 \mathrm{~mm}$. Most sightings were of birds roosting in Paperbarks (Melaleuca raphiophylla) in the south-western corner of the lake.

Recorded: January, February, October to December.

Breeding: None recorded.

Maximum: 25 on 14 February 1993.

\section{Cattle Egret}

Ardea ibis Linnaeus, 1758

Rare visitor. Only records are single birds from 27 February to 4 March 2000 and 11 March 2006, 7 on 2 December 2012 and 21 on 1 January 2014.

\section{White-necked Heron}

\section{Ardea pacifica Latham, 1802}

Generally scarce visitor, with fewer than 5 birds present, although common in years of irruption (2002, 2015 and 2017) when up to 30 birds were present. Primarily recorded from late September to early January with the only record outside this time being a single bird on 19 May 2013.

Recorded: January, May, September to December.

Breeding: None recorded.

Maximum: 30 on 23, 27 and 28 October 2015.

\section{Eastern Great Egret}

\section{Ardea modesta J.E. Gray, 1831}

Uncommon, recorded year round. Generally much more common before 1994 when over 30 birds were regularly recorded but no more than 30 recorded since that year and no more than 10 since 2004. Numbers peaked $(>10)$ between early October and mid-February and when water depth was between 660 and $1100 \mathrm{~mm}$.

Recorded: All months.

Breeding: None recorded.

Maximum: 182 on 12 February 1983.

\section{White-faced Heron \\ Ardea novaehollandiae Latham, 1790}

Common, recorded year round. Highest numbers $(>50)$ present between mid-December and mid-March. Little relationship to water depth below $1,000 \mathrm{~mm}$ but fewer birds were present $(<15)$ above that depth.

Recorded: All months.

Breeding: None recorded.

Maximum: 409 on 2 February 2018 


\section{Little Egret}

\section{Ardea garzetta Linnaeus, 1766}

Scarce visitor, only recorded during spring and summer from mid-October to mid-March. The few observations did not correspond to any particular water depth.

Recorded: January to March, October to December.

Breeding: None recorded.

Maximum: 2 on 12 March 1993, 18 December 2005 and 11 January 2012.

\section{Australian Pelican}

\section{Pelecanus conspicillatus Temminck, 1824}

Frequent, recorded year round. Numbers peaked $(>50)$ between early October and mid-March and most common $(>12)$ when water depth was below $680 \mathrm{~mm}$. This species appeared to use the lake primarily as a resting area.

Recorded: All months.

Breeding: None recorded but breeding in nearby Peel Inlet from late August to February.

Maximum: 199 on 15 March 2009.

\section{Little Pied Cormorant}

\section{Phalacrocorax melanoleucos (Vieillot, 1817)}

Common, recorded most of the year. Highest numbers present $(>30)$ from late August to late January and when water depth was above $330 \mathrm{~mm}$.

Recorded: January to April, June to December.

Breeding: A small colony of 9-16 pairs recorded on west side of lake in September to November 1997. About 10 nests recorded at same place in September 1999.

Maximum: 143 on 28 December 1995.

\section{Little Black Cormorant \\ Phalacrocorax sulcirostris (von Brandt, 1837)}

Uncommon, rarely more than 40 birds present. Recorded primarily in spring and summer and apparently absent from May to June. Greatest abundance $(>25)$, from late September to late January, coincided with breeding season in nearby Lake Mealup. Numbers peaked $(>40)$ when water depth was greater than $930 \mathrm{~mm}$ and not recorded when water levels were below $420 \mathrm{~mm}$.

Recorded: January to April, July to December.

Breeding: Not recorded.

Maximum: 415 on 28 September 2008.

\section{Pied Cormorant \\ Phalacrocorax varius (Gmelin, 1789)}

Scarce visitor. Only records were single birds on 25 January 1997, 25 October 1998, 31 July 1999, 20 October 2007 and 6 January 2018 and two birds on 19 December 1999 and 27 February 2000.

\section{Great Cormorant}

Phalacrocorax carbo (Linnaeus, 1758)

Uncommon, rarely more than 8 birds present. Not obviously more abundant in any month or associated with any water depth. Usually observed roosting in dead Paperbarks (Melaleuca raphiophylla) at north end of lake.

Recorded: All months.

Breeding: Not recorded.

Maximum: 16 on 1 March 1985.

\section{Australasian Darter \\ Anhinga novaehollandiae (Gould, 1847)}

Uncommon, rarely more than 11 birds present. Recorded most of the year with numbers peaking $(>11)$ in January and February. Not strongly related to water depth but generally more common at greater depth. Unusually abundant in 1992 and 1993, when up to 30 were present and breeding.

Recorded: January to April, June to December.

Breeding: Nests with young seen on 21 April 1992.

Maximum: 30 on 2 January 1992.

\section{Osprey}

\section{Pandion haliaetus (Linnaeus, 1758)}

Uncommon. First record was on 21 November 2000 but seen regularly since then. No obvious relationship with water depth or time of year.

Recorded: All months.

Breeding: A pair bred regularly in a dead Tuart (Eucalyptus gomphocephala) just outside the southwestern part of the reserve. Probably bred most years.

Maximum: 5 on 18 November 2001.

\section{Swamp Harrier}

\section{Circus approximans Peale, 1848}

Frequent. No temporal patterns to occurrence and numbers show no relationship with water depth.

Recorded: All months.

Breeding: None recorded.

Maximum: 8 on 9 December 2000.

\section{White-bellied Sea Eagle}

\section{Haliaeetus leucogaster (Gmelin, 1788)}

Frequent. No obvious temporal pattern to occurrence and no obvious relationship between abundance and water depth.

Recorded: All months.

Breeding: Breeds just outside the reserve in Tuarts (Eucalyptus gomphocephala) on the ridge between the lake and the Peel-Harvey estuary. First recorded breeding in October 1984 with subsequent records being two adults and a recently fledged juvenile in November 2001 and, presumably the same pair, at a different nest in August 2002.

Maximum: 3 on 12 dates between 25 January 1998 and 30 December 2014. 


\section{Buff-banded Rail}

Gallirallus philippensis (Linnaeus, 1766)

Rare visitor. The only records are single birds from 15 April 2006 to 6 May 2006 and on 15 April 1997 and 24 October 2012. Probably more common than the sparse records indicate.

\section{Baillon's Crake \\ Porzana pusilla (Pallas, 1776)}

Scarce, probably absent in winter. Sightings were too few to determine any relationship with water level. Probably more common than the sparse records indicate.

Recorded: January to April, October, November.

Breeding: None recorded.

Maximum: 4 on 26 February 2006.

\section{Australian Spotted Crake Porzana fluminea Gould, 1843}

Uncommon, probably absent from August to September due the absence of suitable water depths. No strong relationship between abundance and water depth but more common when depth was less than $670 \mathrm{~mm}$. Probably more common than records indicate.

Recorded: January to July, October to December.

Breeding: None recorded.

Maximum: 15 on 14 and 17 January 2009.

\section{Spotless Crake}

\section{Porzana tabuensis (Gmelin, 1789)}

Uncommon, probably absent from August to September due the absence of suitable water depths. Numbers peaked $(>5)$ when water depth was less than $470 \mathrm{~mm}$. An unusual observation was made in March 2000 when birds were observed feeding $1.5 \mathrm{~m}$ above the ground in Paperbarks (Melaleuca raphiophylla). Probably more common than records indicate.

Recorded: January to July, October to December.

Breeding: A nest with eggs was found in shrubs at the northern end of the lake in October 1984.

Maximum: 30 on 20 April 1997.

\section{Purple Swamphen \\ Porphyrio porphyrio (Linnaeus, 1758)}

Frequent, recorded most months. Most common $(>10)$ from late November to mid-April and when water depth was between 100 and $240 \mathrm{~mm}$. Has become much less common recently with the only count of more than 4 birds since 2001 being 14 individuals counted on 11 March 2006 and the most recent record being a single bird on 1 November 2014.

Recorded: January to April, June to December.

Breeding: Pairs with chicks in January 1983 and two immature birds were seen in January 2000.

Maximum: 26 on 19 March 1996.

\section{Dusky Moorhen}

\section{Gallinula tenebrosa Gould, 1846}

Scarce, most sightings were of single birds. Not recorded when water depth was below $230 \mathrm{~mm}$ and more likely to be present when water depths were high. Has become much less common recently with the only record since 2001 being a single bird seen on 16 January 2009 .

Recorded: January to March, August to October, December.

Breeding: Four adults seen with two small chicks in January 2000.

Maximum: 6 on 18 March 2000.

\section{Black-tailed Native-hen Tribonyx ventralis (Gould, 1837)}

Uncommon and irregular visitor. Presence erratic and often absent. Numbers peaked $(>3)$ between late October and late January. Abundance does not seem to be associated with any particular water depth.

Recorded: January, February, July to December.

Breeding: None recorded.

Maximum: 24 on 29 January 1992.

\section{Eurasian Coot \\ Fulica atra Linnaeus, 1758}

Very common, recorded most of the year. Numbers peak $(>2,100)$ between late October and mid-April although still common over winter e.g. 1,759 on 29 August 1997. No obvious relationship between abundance and water depth. Numbers can change very rapidly. For example, 10,000 were present on 7 January 1995 but numbers declined sharply to 4,500 on 15 January, to 3,000 on 26 January and 188 on 4 February. Appears to have declined in abundance recently with counts since 2008 being of no more than 300 birds.

Recorded: January to April, June to December.

Breeding: Pair with young in November 1983.

Maximum: 10,000 on 7 January 1995.

\section{Pied Oystercatcher}

\section{Haematopus longirostris Vieillot, 1817}

Very rare visitor. The only record is a single bird on 18 December 2005.

\section{Black-winged Stilt \\ Himantopus himantopus (Linnaeus, 1758)}

Abundant. Numbers highest $(>2,500)$ between late December and early March when water depth was between 100 and $670 \mathrm{~mm}$ but common across a wide range of water depths. For more details see Craig et al. (2001).

Recorded: All months.

Breeding: None recorded.

Maximum: 5,500 on 1 February 2004. 


\section{Banded Stilt \\ Cladorhynchus leucocephalus (Vieillot, 1816)}

Common irregular visitor whose occurrence was very erratic. Recorded most of the year. Numbers peaked $(>500)$ between late November and late February. Most abundant ( $>100)$ when water depth was below $390 \mathrm{~mm}$. Only small numbers $(<93)$ between 390 and $860 \mathrm{~mm}$ and absent above that depth. For more details see Craig et al. (2001).

Recorded: January to August, October to December.

Breeding: None recorded.

Maximum: 5,500 on 5 February 2004.

\section{Red-necked Avocet \\ Recurvirostra novaehollandiae Vieillot, 1816}

Very common visitor. Numbers peaked $(>1,000)$ between late October and late March when the water level was between 110 and $420 \mathrm{~mm}$. Only present when the water depth was below $800 \mathrm{~mm}$. For more details see Craig et al. (2001).

Recorded: All months.

Breeding: None recorded.

Maximum: 7,500 on 5 November 2006.

\section{Banded Lapwing Vanellus tricolor (Vieillot, 1818)}

Scarce visitor. The only sightings were two birds on the 15 June 1997, 22 July 1998, 25 February 2001 and 11 July 2006 and single birds on 28 August 2003, 20 March 2011 and 21 September 2013.

\section{Masked Lapwing}

\section{Vanellus miles (Boddaert, 1783)}

Vagrant. The only record was a single bird of the race novaehollandiae sighted several times between 21 December 2002 and 16 January 2003.

\section{Red-kneed Dotterel \\ Erythrogonys cinctus Gould, 1838}

Uncommon visitor, recorded mostly from spring to autumn with the only winter record being a single bird on 18 July 2013. Apparently more common before 1998 with no more than 10 birds recorded since then. Numbers peaked $(>10)$ between late December and late January and most common $(>5)$ between water depths of 100 and $660 \mathrm{~mm}$. For more details see Craig et al. (2001).

Recorded: January to April, July, October to December.

Breeding: None recorded.

Maximum: 90 on 15 January 1986.

\section{Inland Dotterel}

Peltohyas australis (Gould, 1841)

Vagrant. The only record is a single bird observed from 17 to 19 November 2010.

\section{Pacific Golden Plover}

Pluvialis dominica (Gmelin, 1789)

Uncommon non-breeding visitor from late September to late April. Usually no more than four birds present. The records are too sparse to determine any relationship with water depth. For more details see Craig et al. (2001).

Recorded: January to April, September to December.

Maximum: 10 on 5 March 2006.

\section{Grey Plover \\ Pluvialis squatarola (Linnaeus, 1758)}

Scarce non-breeding visitor from mid-November to mid-January with overwintering birds recorded in 2006 only. Usually only single birds present, occasionally up to five.

Recorded: January, June to August, November, December.

Maximum: 5 on 7 January 2010.

\section{Little Ringed Plover}

\section{Charadrius dubius Scopoli, 1786}

Rare visitor. Two sightings of single birds on 21 March 1992 and 4 February 1995.

\section{Red-capped Plover \\ Charadrius ruficapillus Temminck, 1822}

Very common, present year round. Numbers peaked $(>750)$ from mid-December to mid-February and uncommon from August to October. Most abundant $(>165)$ when the water depth was below $520 \mathrm{~mm}$. The only waterbird species typically present when the lake dried out when up to 574 individuals were recorded on the dry lakebed. For more details see Craig et al. (2001).

Recorded: All months.

Breeding: Many records and probably breeds every year. Records included nests in March 1992, December 1993, December 1998, January 1999 and May 2006 and runners in March 1993, April 1993, February 1996, February 1998, January 1999, May 2000, June 2000, April 2006 and May 2006.

Maximum: 1,165 on 12 January 2008.

\section{Double-banded Plover \\ Charadrius bicinctus Jardine and Selby, 1827}

Scarce visitor. The only records were single birds from 29 May to 3 June 2004, 24 April to 8 July 2006, 15 March to 28 June 2009, on 18 July 2010 and from 5 June to 2 July 2014.

\section{Lesser Sand Plover \\ Charadrius mongolus Pallas, 1776}

Rare visitor. Only observations were single birds on 19 February 1995, 3 February 1999 and 4 February 2013. 


\section{Greater Sand Plover}

Charadrius leschenaultii Lesson, 1826

Scarce non-breeding visitor from early November to late April with one record of two overwintering birds on 15 July 2010 . Normally only one or two birds present. Only observed when water depth was below $365 \mathrm{~mm}$.

Recorded: January, February, April, July, November, December.

Maximum: 4 on 19 November 2006.

\section{Oriental Plover}

\section{Charadrius veredus Gould, 1848}

Very rare visitor. The only record was a single bird from 4 to 20 February 2005.

\section{Hooded Plover \\ Thinornis cucullatus (Vieillot, 1818)}

Very rare visitor. The only record is two birds, presumably a pair, present from 11 to 26 November 2006.

\section{Black-fronted Dotterel}

\section{Elseyornis melanops (Vieillot, 1818)}

Frequent, present most of the year although rare from August to October. Numbers peaked ( $>30)$ between midFebruary and late June and most abundant $(>10)$ when water depth was between 180 and $460 \mathrm{~mm}$. For more details see Craig et al. (2001).

Recorded: January to August, October to December.

Breeding: Three runners in April 1993, three nests with eggs in December 1993 and one nest in May 1997.

Maximum: 75 on 24 April 2000.

\section{Painted Snipe \\ Rostratula benghalensis (Linnaeus, 1758)}

Very rare visitor. The only record is a single bird on 7 December 2012.

\section{Latham's Snipe \\ Gallinago hardwickii (J.E. Gray, 1831)}

Vagrant. The only record is a single individual seen from 14 to 28 January 2009. Also an unidentified Gallinago snipe was seen from 12 to 18 February 1984.

\section{Asian Dowitcher}

Limnodromus semipalmatus (Blyth, 1848)

Vagrant. One bird seen on 21 March 1992. For more details see Blyth and Watkins (1992).

\section{Black-tailed Godwit}

Limosa limosa (Linnaeus, 1758)

Frequent non-breeding visitor. Present most of the year although rare in winter. Numbers peaked $(>5)$ between late December and early April. Not recorded when water levels were above $680 \mathrm{~mm}$. For more details see Craig et al. (2001).

Recorded: January to July, September to December.

Maximum: 65 on 30 March 1989.

\section{Bar-tailed Godwit}

Limosa lapponica (Linnaeus, 1758)

Scarce non-breeding visitor, recorded between November and March. It was unusually common between 7 November and 1 December 2010 when up to 25 birds were present. Outside this period the only records were two birds on 8 February 1997, one bird from 27 February to 19 March 2009, 5 birds on 7 January 2010, three birds on 25 December 2011, three birds on 14 January 2012, three birds on 1 January 2013 and one bird on 27 January 2013.

Recorded: January to March, November, December.

Maximum: 25 on 30 November 2010.

\section{Little Curlew \\ Numenius minutus Gould, 1841}

Very rare non-breeding visitor. One recorded from 19 December 2009 to 10 January 2010.

\section{Whimbrel \\ Numenius phaeopus (Linnaeus, 1758)}

Rare non-breeding visitor. The only records were two seen on 8 February 1997 and 29 September 2010.

\section{Eastern Curlew}

Numenius madagascariensis (Linnaeus, 1766)

Very rare non-breeding visitor. One observed on 9 February 1997.

\section{Marsh Sandpiper}

Tringa stagnatilis (Bechstein, 1803)

Common non-breeding visitor. Present all year but numbers peaked $(>12)$ between early December and early April. Most common (>8) at water depth between 90 and $680 \mathrm{~mm}$ and not recorded at water depths above $960 \mathrm{~mm}$. For more details see Craig et al. (2001).

Recorded: All months.

Maximum: 142 on 29 January 1992.

\section{Common Greenshank}

Tringa nebularia (Gunnerus, 1767)

Very common non-breeding visitor. Numbers peaked $(>65)$ between late December and late March. Most common (>26) between water depths of 90 and $830 \mathrm{~mm}$ and not recorded above water depths of $1,100 \mathrm{~mm}$. For more details see Craig et al. (2001).

Recorded: All months.

Maximum: 300 on 3 January 2004.

\section{Wood Sandpiper \\ Tringa glareola Linnaeus, 1758}

Uncommon non-breeding visitor from late spring to early autumn with the earliest observation being a single bird on 29 September 2010 and the latest being nine birds on 29 April 2006. Numbers peaked $(>20)$ between early December and early March. Most common (>10) between water depths of 330 and $670 \mathrm{~mm}$ and not recorded when the water depth was above 960 $\mathrm{mm}$. Formerly more common with counts before 1996 often exceeding 30 birds. However, no more than 22 
birds recorded since that year and no more than 2 birds recorded since 2009. For more details see Craig et al. (2001).

Recorded: All months.

Maximum: 112 on 3 January 2004.

\section{Grey-tailed Tattler \\ Tringa brevipes (Vieillot, 1816)}

Scarce non-breeding visitor. It was moderately common from 13 December 1998 until 3 February 1999 when up to 18 birds were present. The only records since then were two birds on 17 January 2009 and single birds on 27 December 2002, 24 March 2009 and from 14 to 15 February 2014. For more details see Craig et al. (2001).

Recorded: January to March, December.

Maximum: 18 on 10 January 1999.

\section{Terek Sandpiper}

\section{Xenus cinereus (Güldenstädt, 1775)}

Rare non-breeding visitor. Between one and two birds were present between 22 October and 24 November 2006 but the only other records were two birds on 24 November 2007 and a single bird on 1 February 2009.

\section{Common Sandpiper \\ Tringa hypoleucos Linnaeus, 1758}

Rare non-breeding visitor. Single birds observed on 17 February 1993, 1 February 2009 and 1 January 2014.

\section{Ruddy Turnstone}

\section{Arenaria interpres (Linnaeus, 1758)}

Rare non-breeding visitor. Single birds observed on 12 February 1984, from 28 October to 4 November 2006 and from 7 to 30 November 2010 and two on 10 November 2006.

\section{Great Knot \\ Calidris tenuirostris (Horsfield, 1821)}

Scarce non-breeding visitor. One observed on 6 January 2012, two on 27 April 1997, 5 June 2000 and 11 March 2006, four on 15 January 2013, five on 7 January 2010 and 14 on 8 November 2010.

\section{Red Knot}

\section{Calidris canutus (Linnaeus, 1758)}

Uncommon non-breeding visitor, recorded most years. Present most of the year although primarily recorded from early November to late May with only single birds recorded outside that period and apparently absent in August and September. Most common ( $>2$ ) between water depths of 200 and $365 \mathrm{~mm}$. This species appears to be an irregular visitor to the lake which is unusual as it is generally considered exclusively estuarine and marine (Lane and Davies 1987; Higgins and Davies 1996; Johnstone and Storr 2001) although it has been previously recorded on near coastal lakes on the Swan Coastal Plain (Storr and Johnstone 1988). For more details see Craig et al. (2001).

Recorded: January to July, October to December.

Maximum: 145 on 19 November 2010.

\section{Sanderling}

Calidris alba (Pallas, 1764)

Rare non-breeding visitor. Single birds observed on 3 February 1999, 12 March 2000 and 4 November 2006.

\section{Red-necked Stint \\ Calidris ruficollis (Pallas, 1776)}

Abundant non-breeding visitor. Numbers peaked $(>3,250)$ between early November and mid-March and most common $(>2,000)$ when the water depth was between 90 and $365 \mathrm{~mm}$. This species commonly overwinters with the peak at 3,220 birds on 21 June 2003. For more details see Craig et al. (2001).

Recorded: All months.

Maximum: 11,705 on 17 February 2005.

\section{Little Stint}

\section{Calidris minuta (Leisler, 1812)}

Scarce non-breeding visitor. Single birds recorded on 20 March 1993, from 10 to 31 January 1999, from 2 to 8 December 2001, on 29 December 2002 and on 10 January 2013. Most records were of birds in breeding plumage so potentially more regular than the sparse records suggest. For more details see Craig et al. (2001).

\section{Long-toed Stint \\ Calidris subminuta (Middendorff, 1853)}

Uncommon non-breeding visitor. Numbers peaked $(>8)$ between early November and mid-March and rare from June to September with only two records of single birds over that period. Most common ( $>4$ ) between water depths of 125 and $540 \mathrm{~mm}$. Appears to have declined in abundance with maximum counts before 1994 regularly exceeding 40 birds but the highest count since 1994 being 33 on 20 November 2002 and the maximum count since 2009 being 14 on 22 February and 26 November 2014. For more details see Craig et al. (2001).

Recorded: January to May, July, September to December.

Maximum: 96 on 8 March 1992.

\section{Baird's Sandpiper Calidris bairdii (Coues, 1861)}

Vagrant. One record, a single bird on 14 January 2017.

\section{Pectoral Sandpiper}

\section{Calidris melanotos (Vieillot, 1819)}

Uncommon non-breeding visitor. Absent in winter and rare in May and September with the only records in those months being one on 8 May 1993 and two on 16 September 2006, these being the latest and earliest dates for this species. Numbers peaked $(>3)$ between early November and mid-April. Most common ( $>2$ ) between water depths of 90 and $420 \mathrm{~mm}$. For more details see Craig et al. (2001).

Recorded: January to May, September to December. Maximum: 24 on 8 January 2014 and 29 December 2014. 


\section{Sharp-tailed Sandpiper \\ Calidris acuminata (Horsfield, 1821)}

Very common non-breeding visitor. Very rarely overwinters with the only records being one bird on 11 July 2006 and two on 3 August 2001. Apart from these two records, the earliest and latest dates for this species are two on 9 September 2012 and one on 29 April 2006. Numbers peaked $(>1,000)$ between early November and mid-March and most common $(>1,600)$ when water depth was between 90 and $360 \mathrm{~mm}$. Not recorded when water depth exceeded $830 \mathrm{~mm}$. For more details see Craig et al. (2001).

Recorded: January to April, July to December.

Maximum: 5,970 on 16 January 2003.

\section{Curlew Sandpiper \\ Calidris ferruginea (Pontoppidan, 1763)}

Very common non-breeding visitor although much less common recently. Numbers peaked $(>800)$ from early December to late March. Commonly overwinters with a peak of 547 on 17 June 2006. Most common (>500) when water depth was between 90 and $420 \mathrm{~mm}$ and no more than single birds when water depth was above $680 \mathrm{~mm}$. This species has become less common recently with the highest count since 2010 being only 120 birds on 7 January 2017. For more details see Craig et al. (2001).

Recorded: All months.

Maximum: 3,000 on 30 March 1989.

\section{Broad-billed Sandpiper Limicola falcinellus (Pontoppidan, 1763)}

Scarce non-breeding visitor, not recorded every year. Primarily present from late October to mid-March but single individuals overwintered from 17 June to 19 July 2006 and from 15 to 24 July 2010. Only recorded between water depths of 125 and $365 \mathrm{~mm}$. For more details see Craig et al. (2001).

Recorded: January to March, June, July, October to December.

Maximum: 2 on five dates from 4 February 1996 to 28 December 2014.

\section{Ruff \\ Philomachus pugnax (Linnaeus, 1758)}

Scarce non-breeding visitor. Mostly present from late October to mid-March with the only record outside that period being a single bird on 8 May 1993. Most records were when water depth was between 90 and $390 \mathrm{~mm}$ with only two records at greater depths of two birds on 24 November 2004 at $540 \mathrm{~mm}$ and on 24 December 2004 at $670 \mathrm{~mm}$. For more details see Craig et al. (2001).

Recorded: January to March, May, October to December.

Maximum: 5 on 12 February 1983 to 12 March 1989.

\section{Oriental Pratincole \\ Glareola maldivarum J.R. Forster, 1795}

Rare non-breeding visitor. The only records are five birds on 1 March 1985 with 10 birds present the next day and single birds on 31 January 1987, 27 January 1989 and from 26 to 28 November 2010. For more details see Craig et al. (2001).

\section{Silver Gull}

\section{Larus novaehollandiae Stephens, 1826}

Common, present all year. Previously rare at the lake, only a few records pre-1995, this species has become more common recently. Numbers peaked $(>60)$ between early November and mid-May and $(>115)$ between water depths of 120 and $610 \mathrm{~mm}$.

Recorded: All months.

Breeding: None recorded.

Maximum: 1,764 on 7 February 2009.

\section{Gull-billed Tern}

\section{Sterna nilotica Gmelin, 1789}

Scarce visitor. The only records are three birds on 18 December 2011 and 30 October 2014, two birds on 18 November 2011 and 2 November 2014 and single birds on 14 December 2008 and 18 January 2013.

\section{Caspian Tern}

\section{Sterna caspia Pallas, 1770}

Scarce visitor, rarely more than six birds present. Present most of the year and primarily recorded between late December and late July, only scattered records of one or two birds at other times. No obvious relationship between numbers and water depth but not recorded above depths of $800 \mathrm{~mm}$.

Recorded: January to April, June to August, November, December.

\section{Breeding: None recorded}

Maximum: 125 on 2 April 1989.

\section{Fairy Tern \\ Sterna nereis Gould, 1843}

Very rare visitor. The only record is two birds on 5 June 2000.

\section{Whiskered Tern}

\section{Sterna hybrida Pallas, 1811}

Frequent visitor. Recorded primarily from late September to late February with the only records outside this period being single birds on 1 April 1990 and 25 May 2000 and two birds on 28 May 2000. Numbers peaked $(>65)$ between late December and early February and most common $(>6)$ between water depths of 110 and $800 \mathrm{~mm}$.

Recorded: January, February, April, May, September to December.

Breeding: None recorded.

Maximum: 350 on 11 January 2004 


\section{White-winged Black Tern}

Sterna leucoptera Temminck, 1815

Uncommon and irregular non-breeding summer visitor. Recorded only from late November to late February but presence very erratic and often absent.. Numbers peaked $(>4)$ between late December and late January and most common $(>1)$ between water depths of 300 and $420 \mathrm{~mm}$.

Recorded: January, February, November, December.

Maximum: 110 on 22 January 1996.

\section{Australian Reed Warbler}

\section{Acrocephalus australis (Gould, 1838)}

Scarce, present most of the year but rare or absent in winter. No obvious monthly peaks in abundance. Most common (>1) when water depth was above $390 \mathrm{~mm}$ but the relationship with water depth was not strong. Primarily recorded in clumps of Typha.

Recorded: January, February, April, May, August to December.

Breeding: None recorded.

Maximum: 6 on 30 December 1996 and 16 September 2006.

\section{Little Grassbird}

Megalurus gramineus (Gould, 1845)

Frequent, recorded year round. Numbers appeared to peak $(>8)$ between late September and early January but this may be because birds were calling at this time and hence more obvious. Most common $(>7)$ when water levels were above $950 \mathrm{~mm}$ and not recorded when water level below $180 \mathrm{~mm}$. This apparent preference for high water levels may be because these water levels coincide with the time of the year when most birds were calling. Mainly recorded in Melaleuca thickets with some records from Typha clumps.

Recorded: All months.

Breeding: None recorded.

Maximum: 20 on 23 November and 30 December 2008.

\section{LANDBIRDS}

\section{Emu}

Dromaius novaehollandiae (Latham, 1790)

Uncommon, presumably resident. Seen primarily during summer and rare, or absent in autumn. Observations range from single birds to groups of 11 .

Recorded: January, February, May to December.

Breeding: None recorded although immature birds were frequently sighted.

\section{Stubble Quail}

\section{Coturnix pectoralis Gould, 1837}

Uncommon, presumably resident with no obvious seasonal peak in abundance, although considered a visitor to the Swan Coastal Plain (Storr and Johnstone 1988). First recorded in January 2008 but seen regularly since then.

Recorded: January, February, April to September, November, December.

Breeding: None recorded.

\section{Black-shouldered Kite \\ Elanus caeruleus (Desfontaines, 1789)}

Uncommon, presumably resident with sightings regularly throughout the year. Seen singly or in pairs.

Recorded: All months.

Breeding: None recorded.

\section{Square-tailed Kite}

\section{Hamirostra isura (Gould, 1838)}

Scarce, presumably a post-breeding visitor. There are 11 observations of single birds from early October to early February.

Recorded: January, February, October to December.

Breeding: None recorded.

\section{Little Eagle}

Hieraaetus morphnoides (Gould, 1841)

Frequent, presumably resident. Usually seen singly, rarely in pairs.

Recorded: All months.

Breeding: None recorded.

\section{Wedge-tailed Eagle}

\section{Aquila audax (Latham, 1802)}

Uncommon, presumably resident. Sightings of single birds and pairs. Immature sighted in January 1999.

Recorded: All months.

Breeding: None recorded.

\section{Brown Goshawk}

Accipter fasciatus (Vigors and Horsfield, 1827)

Uncommon, presumably resident with records scattered throughout the year. All sightings were of single birds.

Recorded: January to April, July, September to December.

Breeding: None recorded.

\section{Collared Sparrowhawk}

\section{Accipter cirrocephalus (Vieillot, 1817)}

Scarce, presumably resident although no records in autumn. The species is considered resident, a postbreeding nomad and a winter visitor on the Swan Coastal Plain (Storr and Johnstone 1988) so there is likely to be some movement of birds at the lake. All sightings were of single birds.

Recorded: January, February, June, August to December.

Breeding: None recorded. 


\section{Whistling Kite}

\section{Haliastur sphenurus (Vieillot, 1818)}

Common, presumably resident with sightings regularly throughout the year but probably also some additional birds are summer-autumn visitors (Storr and Johnstone 1988). Usually seen singly but groups of up to eight have been recorded around Black Swan carcasses.

Recorded: All months.

Breeding: Bred just outside the southern boundary of the reserve in a Tuart (Eucalyptus gomphocephala) in July 1997.

\section{Common Bronzewing \\ Phaps chalcoptera (Latham, 1790)}

Uncommon, presumably resident. Most common between July and January. Generally seen as single birds but sometimes in small flocks of up to nine birds.

Recorded: January, March, July to December.

Breeding: None recorded.

\section{Crested Pigeon \\ Ocyphaps lophotes (Temminck, 1822)}

Common, presumably resident. Generally in small groups of less than four birds but sometimes in flocks of up to 46.

Recorded: All months.

Breeding: None recorded.

\section{Horsfield's Bronze Cuckoo Chrysococcyx basalis (Horsfield, 1821)}

Rare visitor. Two sightings of single birds on 30 October 1994 and 17 January 2009.

\section{Shining Bronze-Cuckoo Chrysococcyx lucidus (Gmelin, 1788)}

Common breeding visitor. Usually seen singly or in pairs. Earliest sighting was on 15 July and the latest sighting was on 3 February.

Recorded: January, February, July to December.

Breeding: None recorded.

\section{Pallid Cuckoo}

\section{Cacomantis pallidus (Latham, 1802)}

Scarce, presumably a breeding visitor. The only records were single birds on 31 July 1997, 22 July 2002, 21 June 2003, 28 August 2003, 11 July 2006, 11 September 2010 and 8 November 2014 and two birds on 30 July 2005.

\section{Fan-tailed Cuckoo}

Cacomantis flabelliformis (Latham, 1802)

Uncommon, presumably a breeding visitor. Seen singly or in pairs. Earliest sighting was on 19 May and the latest sighting was on 12 November.

Recorded: May to September, November.

Breeding: None recorded.

\section{Boobook Owl}

\section{Ninox boobook (Latham, 1801)}

Rare, presumably resident or passage migrant (Storr and Johnstone 1988). The only observation is a single bird on 2 August 1998. Undoubtedly more common as very few visits were conducted at night.

\section{Pacific Swift}

Apus pacificus (Latham, 1802)

Rare non-breeding visitor. The only record was one bird sighted on 19 February 1995.

\section{Laughing Kookaburra \\ Dacelo novaeguineae (Hermann, 1783)}

Common, presumably resident with no monthly peak in abundance. Seen singly or in groups of up to four.

Recorded: All months.

Breeding: None recorded.

\section{Sacred Kingfisher}

Todiramphus sancta (Vigors and Horsfield, 1827)

Common breeding visitor in spring and summer, also passage migrant. Rare in autumn (March to May), where the only records are single birds on 12 March 1993, 5 May 2006 and 19 May 2013 and absent in winter (June to August). Generally seen singly or in pairs. Earliest sighting was on 19 September and the latest sighting was on 19 May.

Recorded: January to March, May, September to December.

Breeding: Birds were seen leaving hollows in Flooded Gums (Eucalyptus rudis) around the lake in November 1997 and September 1999.

\section{Rainbow Bee-eater \\ Merops ornatus Latham, 1802}

Very common breeding visitor in spring and summer. Generally in small groups of up to five during the breeding season but in flocks of up to 50 at other times. Earliest sighting was on 7 October and the latest sighting was on 25 February.

Recorded: January, February, October to December.

Breeding: Recorded entering nest burrow along road adjacent to the south side of the reserve in November 1997.

\section{Australian Kestrel}

Falco cenchroides (Vigors and Horsfield, 1827)

Common, presumably resident. Usually seen as single birds.

Recorded: All months.

Breeding: None recorded. 


\section{Australian Hobby}

\section{Falco longipennis Swainson, 1837}

Uncommon, presumably resident. Mainly single birds, sometimes in pairs.

Recorded: January, February, April, May, July to December.

Breeding: None confirmed but a pair were seen displaying and landing on an old nest in a Tuart (Eucalyptus gomphocephala) in July 1997.

\section{Brown Falcon}

\section{Falco berigora Vigors and Horsfield, 1827}

Scarce, presumably resident. There are eight observations of single birds scattered throughout the year.

Recorded: January, February, May, June, October, November.

Breeding: None recorded.

\section{Peregrine Falcon \\ Falco peregrinus Tunstall, 1771}

Frequent, presumably resident. Usually seen singly, occasionally in pairs. Not infrequently seen capturing waders and ducks over the lake.

Recorded: January to April, June to December.

Breeding: None recorded.

\section{Red-tailed Black-Cockatoo Calyptorhynchus banksii (Latham, 1790)}

Uncommon, presumably a visitor from the nearby Darling range. Present from spring to autumn, absent in winter. Earliest date is 16 September and latest date is 29 May. Usually in small flocks of up to four birds although a flock of 15 was sighted once. Birds have been recorded feeding on Marri (Corymbia calophylla) within the reserve.

Recorded: January to May, September to December.

Breeding: None recorded.

\section{Carnaby's Cockatoo \\ Calyptorhynchus latirostris Carnaby, 1948}

Frequent, presumably mainly a non-breeding visitor but recorded throughout the year so small numbers possibly resident. Mostly recorded singly, in pairs or in small flocks of up to nine but largest flock recorded contained 45 birds.

Recorded: All months.

Breeding: None recorded.

\section{Galah}

\section{Cacatua roseicapilla Vieillot, 1817}

Frequent, presumably resident as recorded regularly throughout the year. Seen singly, in pairs or small flocks of up to 17

Recorded: All months.

Breeding: None recorded.
Little Corella

Cacatua sanguinea Gould, 1843

Frequent, presumably resident as recorded most of the year. Usually seen in small flocks of up to 30 birds.

Recorded: January, February, April to December.

Breeding: None recorded.

\section{Sulphur-crested Cockatoo}

Cacatua galerita (Latham, 1790)

Common, presumably resident. Usually seen in small flocks of up to eight birds, rarely up to 60 . This species was common up until 2001 when the birds were culled by the Department of Agriculture but culling has not continued and numbers subsequently recovered with 11 birds recorded on 26 February 2012.

Recorded: All months.

Breeding: None recorded.

\section{Red-capped Parrot}

Platycercus spurius (Kuhl, 1820)

Frequent, presumably resident. Generally seen singly or in pairs, occasionally in groups of up to four.

Recorded: All months.

Breeding: None recorded.

\section{Australian Ringneck}

Platycercus zonarius (Shaw, 1805)

Abundant, presumably resident. Observed primarily in pairs or small groups of up to 5 during the breeding season and in flocks of up to 40 at other times of the year. All records were of the subspecies semitorquatus, zonarius or hybrids between the two.

\section{Recorded: All months.}

Breeding: Birds breed in Tuart (Eucalyptus gomphocephala) along the western edge of the reserve and presumably in eucalypts in the eastern part of the reserve as well. Breeding recorded in most years.

\section{Western Rosella}

Platycercus icterotis (Temminck and Kuhl, 1820)

Vagrant. The only record is a single bird on 23 November 2010. The possibility that it was an escaped cagebird cannot be excluded as the nearest natural populations occur $25 \mathrm{~km}$ to the east.

\section{Elegant Parrot \\ Neophema elegans (Gould, 1837)}

Uncommon, presumably a non-breeding visitor. Primarily occurs from late autumn to early spring. The only records outside that period were three birds on 30 January 2000 and 4 January 2013. Generally seen singly, in pairs or in flocks of up to 30. First recorded on 19 September 1999 but has become more common recently with sightings now annual.

Recorded: January, April to September.

Breeding: None recorded. 


\section{Regent Parrot}

Polytelis anthopeplus (Lear, 1831)

Common, presumably resident. Generally seen in small flocks of up to 10 birds.

Recorded: All months.

Breeding: Breeds in Tuarts (Eucalyptus gomphocephala) along the western edge of the reserve where a pair was seen entering a nesting hollow in October 1999. Probably breeds annually.

\section{Splendid Fairy Wren}

Malurus splendens (Quoy and Gaimard, 1830)

Very common, presumably resident. Usually seen in groups of four to 10 .

Recorded: All months.

Breeding: None recorded.

\section{Southern Emu-wren}

\section{Stipiturus malachurus (Shaw, 1798)}

Rare visitor. The only records were of a female on 27 December 2002, a pair on 8 January 2017 and three birds on 21 January 2017. All records were in paperbarks (Melaleuca teretifolia) in the south-eastern corner of the lake. As the reserve contains no suitable habitat for this species, these records were presumably of dispersing individuals.

\section{Western Spinebill}

\section{Acanthorhynchus superciliosus Gould, 1837}

Uncommon, recorded for most of the year but presumably with some local movements. Seen singly or in pairs.

Recorded: January to November.

Breeding: None recorded.

\section{Brown Honeyeater}

Lichmera indistincta (Vigors and Horsfield, 1827)

Frequent, presumably primarily breeding visitor but recorded all year. Most common from May to December, scarce outside this period. Abundance varied and the species was very common at times. Generally seen singly or in small groups of up to five.

Recorded: All months.

Breeding: None recorded.

\section{New Holland Honeyeater}

Phylidonyris novaehollandiae (Latham, 1790)

Uncommon, recorded for most of the year but presumably with some local movements. Usually seen singly or in small loose groups of up to five.

Recorded: January to November.

Breeding: None recorded.

\section{Western White-naped Honeyeater Melithreptus chloropsis Gould, 1848}

Scarce post-breeding visitor. The only records are five birds on 24 May 2009 and 4 June 2011, four birds on 21 April 2007, two birds on 29 May 2004 and a single bird on 22 January 1998.

\section{White-fronted Chat}

Ephthianura albifrons (Jardine and Selby, 1828)

Common, recorded throughout the year but presumably with some local movements. Very irregular in occurrence and often absent. Most common from February to April when flocks of over 100 birds have been recorded on the drying lake fringes. Usually in small flocks of up to 30 birds.

Recorded: All months.

Breeding: None recorded.

\section{Western Little Wattlebird}

Anthochaera lunulata Gould, 1838

Rare visitor. The only records are single birds on 2 October 2010 and 6 June 2014.

\section{Red Wattlebird}

Anthochaera carunculata (Shaw, 1790)

Very common, recorded year round but probably subject to local movements as not always present. Seen singly or in flocks of up to 16 .

Recorded: All months.

Breeding: Recorded breeding in the reserve in November 1998.

\section{Singing Honeyeater}

\section{Gavicalis virescens (Vieillot, 1817)}

Scarce, presumably resident as records are scattered throughout the year. Seen singly.

Recorded: January, February, May, September, November, December.

Breeding: None recorded.

\section{Yellow-plumed Honeyeater}

Ptilotula ornata (Gould, 1838)

Vagrant. The only record was a single individual on 4 June 2011.

\section{Spotted Pardalote}

Pardalotus punctatus (Shaw, 1792)

Rare autumn transient. The only records were single birds on 12 April 2008 and 8 April 2014.

\section{Striated Pardalote}

\section{Pardalotus striatus (Gmelin, 1789)}

Common, probably a partial migrant with some birds leaving the area over winter. Numbers appeared lower in winter and higher in spring but this may reflect the amount of calling activity. Usually observed singly or in pairs, occasionally small groups of up to six.

Recorded: All months.

Breeding: None recorded.

\section{White-browed Scrubwren}

Sericornis frontalis (Vigors and Horsfield, 1827)

Common, presumably resident. Usually seen singly or in pairs.

Recorded: All months.

Breeding: None recorded. 
Weebill

Smicrornis brevirostris (Gould, 1838)

Uncommon, presumably resident. Seen singly or in small groups of up to four.

Recorded: All months.

Breeding: None recorded.

\section{Western Gerygone \\ Gerygone fusca (Gould, 1838)}

Common, probably a partial migrant with some birds leaving the area over winter. Records suggest that it was less common in winter and more common in spring but this may partly reflect calling activity.

Recorded: All months.

Breeding: None recorded.

\section{Broad-tailed Thornbill}

\section{Acanthiza apicalis Gould, 1847}

Very common, presumably resident. Usually seen singly or in pairs.

Recorded: All months.

Breeding: None recorded.

Yellow-rumped Thornbill

Acanthiza chysorrhoa

(Quoy and Gaimard, 1830)

Common, presumably resident. Usually seen in small groups of three to six.

Recorded: All months.

Breeding: Breeding in September 1997. Three old nests were found in paperbark trees in September 2002.

\section{Black-faced Woodswallow \\ Artamus cinereus Vieillot, 1817}

Uncommon, presumably resident. Seen in groups of up to five birds. Far more common in the farmland around the reserve than in the reserve itself.

Recorded: All months.

Breeding: None recorded.

\section{Dusky Woodswallow}

Artamus cyanopterus (Latham, 1802)

Scarce and irregular winter and spring visitor. Earliest date is 13 June and latest date is 24 November. Seen in groups of up to four birds.

Recorded: June, July, September to December.

Breeding: None recorded.

\section{Grey Butcherbird}

Cracticus torquatus (Latham, 1802)

Common, presumably resident. Usually seen singly or in pairs.

Recorded: January to March, July to December.

Breeding: None recorded.

\section{Australian Magpie}

\section{Cracticus tibicen (Latham, 1802)}

Very common, presumably resident. Usually seen in groups of up to nine birds.

Recorded: All months.

Breeding: Nest building observed in August 1998.

\section{Grey Currawong}

Strepera versicolor (Latham, 1802)

Very rare visitor. One observed in the southern part of the reserve on 5 February 2006.

\section{Black-faced Cuckoo Shrike}

\section{Coracina novaehollandiae (Gmelin, 1789)}

Frequent, presumably resident but may be subject to local movements as this species seems less common in March and April. Usually seen singly or in pairs.

Recorded: January to March, May to December.

Breeding: None recorded.

\section{White-winged Triller}

\section{Lalage tricolor (Swainson, 1825)}

Rare visitor. The only records were a single bird on 2 November 2014 and a very unusual overwintering bird on 25 June 2009.

\section{Varied Sittella}

Daphoenositta chrysoptera (Latham, 1802)

Scarce, presumably resident. Recorded in groups of up to eight birds.

Recorded: January, May, June, September to December.

Breeding: None recorded.

\section{Western Golden Whistler \\ Pachycephala occidentalis Ramsay, 1878}

Frequent, presumably resident as recorded regularly throughout the year. Seen singly or in pairs.

Recorded: All months.

Breeding: None recorded.

\section{Rufous Whistler}

Pachycephala rufiventris (Latham, 1802)

Common, presumably resident. Seen singly or in pairs. Recorded: All months.

Breeding: None recorded.

\section{Grey Shrike-thrush}

\section{Colluricincla harmonica (Latham, 1802)}

Uncommon, presumably resident. Only solitary birds seen.

Recorded: All months.

Breeding: None recorded.

\section{Willie Wagtail}

Rhipidura leucophrys (Latham, 1802)

Very common, presumably resident. Usually seen singly or in pairs. 
Recorded: All months.

Breeding: One carrying nest material in September 1999.

\section{Grey Fantail}

\section{Rhipidura fuliginosa Gould, 1840}

Very common, probably a partial migrant as numbers were lower from April to July. Seen singly or in groups of up to 15.

Recorded: All months.

Breeding: Adults attending dependent young in October 1990

\section{Magpie-lark}

Grallina cyanoleuca (Latham, 1802)

Very common, presumably resident. Usually seen in pairs, sometimes singly or in family groups of three or four.

Recorded: All months.

Breeding: Nest seen in Flooded Gum (Eucalyptus rudis) in September 1997.

\section{Australian Raven}

Corvus coronoides Vigors and Horsfield, 1827

Very common, presumably resident. Seen singly, in pairs or in flock of up to 15 .

Recorded: All months.

Breeding: None recorded.

\section{Scarlet Robin}

\section{Petroica boodang (Lesson, 1838)}

Uncommon, presumably resident. Seen singly or in pairs.

Recorded: All months.

Breeding: None recorded.

\section{Barn Swallow}

\section{Hirundo rustica Linnaeus, 1758}

Rare visitor. The only records were single birds on 25

February 2006 and from 23 to 24 December 2011.

\section{Welcome Swallow}

\section{Hirundo neoxena Gould, 1842}

Abundant, some evidence of local movements as this species was more abundant (often $>100$ ) from midNovember to mid-April. Seen in groups of hundreds. Often seen roosting in reedbeds or on the dry lake bed with Tree Martins. The largest number recorded was 1,800 on the 4 March 2000.

Recorded: All months.

Breeding: Breeds in old cowsheds, below homestead on southern boundary of reserve.

\section{Fairy Martin}

\section{Cecropis ariel (Gould, 1842)}

Very rare visitor. The only record was a single bird seen on 7 December 1997.

\section{Tree Martin}

\section{Cecropis nigricans (Vieillot, 1817)}

Abundant, likely a partial migrant with some birds leaving the area in winter (Storr and Johnstone 1988) as this species was more common (often $>600$ ) between late December and mid-March. Rarely, seen in flocks of thousands. The largest number recorded was 8,000 on 23 February 1997 when almost all the birds were roosting on the drying lakebed.

\section{Recorded: All months.}

Breeding: Birds seen entering tree hollows in a dead Tuart (Eucalyptus gomphocephala) on the southern boundary of the reserve in November 1999.

\section{Rufous Songlark \\ Cinclorhamphus mathewsi (Iredale, 1911)}

Rare breeding visitor. The only records were a male singing along the north-east edge of the lake on 27 December 1985 and further single birds on 6 January 2013 and 8 November 2014. More common in surrounding farmland.

\section{Brown Songlark \\ Cinclorhamphus cruralis \\ Vigors and Horsfield, 1827}

Scarce breeding visitor. The only records were two birds on 30 December 2008 and single birds on 29 March 2008, 11 December 2011, 9 September 2012, 16 and 24 October 2012 and 22 November 2012. More common in surrounding farmland.

\section{Grey-breasted White-eye} Zosterops lateralis (Latham, 1802)

Very common, probably subject to local movements as numbers were highly variable. Usually seen in flocks of up to 20 birds.

\section{Recorded: All months.}

Breeding: Nest found in Paperbarks (Melaleuca raphiophylla) in October 1998.

\section{Yellow Wagtail}

\section{Motacilla flava Linnaeus, 1758}

Scarce non-breeding visitor. The only records were a single bird of the subspecies simillima on 29 December 1993 and single birds (subspecies undetermined) on 11 March 1997, 2 January 2005 and 19 December 2009.

\section{Australian Pipit}

\section{Anthus australis Vieillot, 1818}

Frequent, presumably resident although less common in September and October when the lake edge is typically flooded. Generally seen singly, rarely in small flock of up to six birds.

Recorded: All months.

Breeding: None recorded.

\section{Red-throated Pipit}

Anthus cervinus Pallas, 1811

Vagrant. The only record is a well-watched individual from 25 January to 9 February 2014. 


\section{DISCUSSION}

Lake McLarty it a critically important wetland of great local, national and international significance. Despite being part of a Wetland of International Importance, the Peel-Yalgorup system, Lake McLarty qualifies as a wetland of international importance in its own right. It supports globally significant populations ( $>1 \%$ of global population) of six species (Grey Teal, Banded Stilt, Red-necked Avocet, Red-capped Plover, Red-necked Stint and Sharp-tailed Sandpiper) and more than $1 \%$ of the East Asian-Australian Flyway (EAAF) of an additional species (Curlew Sandpiper: Table 3). For these species, the $1 \%$ threshold was exceeded on between 1 and 50 dates (Table 3), indicating that the lake is consistently globally significant for some of those species (Ramsar 2018). Furthermore, Lake McLarty has also supported $>20,000$ waterbirds on 19 different dates which is a further criterion for listing it as a Wetland of International Importance (Ramsar 2018: Table 2).

The importance of Lake McLarty is primarily in the quality of the feeding habitat it provides for a large number and diversity of waterbirds rather than supporting significant numbers of breeding birds. Only 18 species have been recorded breeding at the lake and, of these, only four species (Black Swan, Pacific Black Duck, Grey Teal and Red-capped Plover) are suspected of breeding every year. The lake was not considered to be an important breeding location in previous surveys either (Jaensch et al. 1988; Storey et al. 1993). The lake is important for moulting Australian Shelduck with large numbers recorded at the lake in October and November, although numbers are not globally significant, and the lake also acts as a resting place for several species (e.g. Australian Pelican, Caspian Tern) that range across the Peel-Yalgorup system but utilise the lake neither for breeding nor feeding. Lake McLarty Nature Reserve also provides important habitat and connectivity for a wide range of landbirds. Although only one globally threatened species (Carnaby's Cockatoo - Endangered) and one threatened subspecies (Red-tailed BlackCockatoo ssp. naso - Vulnerable) have been recorded within the reserve, the native vegetation supports resident populations of numerous species dependent on native vegetation (e.g. Common Bronzewing, Red-capped Parrot, Rainbow Bee-eater, Tree Martin, Western Little Wattlebird, Scarlet Robin, Grey Shrikethrush, Western Thornbill, Western Spinebill, Inland Thornbill, White-browed Scrubwren, Yellow-rumped

TABLE 3 Internationally significant numbers of the seven species where Lake McLarty has supported $>1 \%$ of the global or flyway populations. Also shown are the number of dates in each month and year when those thresholds have been exceeded (indicated by number after each month or year) as well as the total number of dates when the threshold was exceeded. ${ }^{*}=$ flyway population.

\begin{tabular}{|c|c|c|c|c|}
\hline Species & $\begin{array}{l}1 \% \text { global or } \\
\text { flyway population }\end{array}$ & $\begin{array}{l}\text { Number of } \\
\text { dates }\end{array}$ & Months exceeded & Years exceeded \\
\hline Grey Teal & 11,200 & 3 & $\begin{array}{l}\text { December (1), January (1), } \\
\text { February (1) }\end{array}$ & 1996 (1), 1998 (1), 2002 (1) \\
\hline Banded Stilt & 3,700 & 1 & February (1) & $2004(1)$ \\
\hline Red-necked Avocet & 1,100 & 40 & $\begin{array}{l}\text { October (2), November (11), } \\
\text { December (7), January (6) } \\
\text { February (13), March (1) }\end{array}$ & $\begin{array}{l}1989 \text { (1), } 1991 \text { (2), } 1993 \text { (1), } \\
1994 \text { (2), } 1996 \text { (1), } 1997 \text { (3), } \\
1998 \text { (5), } 2001 \text { (1), } 2004 \text { (4), } \\
2005 \text { (3), } 2006 \text { (9), } 2007,(3), \\
2009 \text { (2), } 2010 \text { (3) }\end{array}$ \\
\hline Red-capped Plover & 950 & 4 & $\begin{array}{l}\text { December (2), January (1), } \\
\text { February (1) }\end{array}$ & 2002 (2), 2008 (1), 2014 (1) \\
\hline Red-necked Stint & 3,200 & 32 & $\begin{array}{l}\text { June (1), November (5), } \\
\text { December (7), January (8), } \\
\text { February (8), March (3) }\end{array}$ & $\begin{array}{l}1996 \text { (2), } 1997 \text { (1), } 1998 \text { (1), } \\
1999 \text { (4), } 2002 \text { (5), } 2003 \text { (3), } \\
2004 \text { (1), } 2005 \text { (3), } 2006 \text { (3), } \\
2008 \text { (1), } 2009 \text { (4), } 2010 \text { (4) }\end{array}$ \\
\hline Sharp-tailed Sandpiper & 1,600 & 50 & $\begin{array}{l}\text { November (7), December (15), } \\
\text { January (15), February (12), } \\
\text { March (1) }\end{array}$ & $\begin{array}{l}1993(1), 1994 \text { (1), } 1998 \text { (4), } \\
1999 \text { (3), } 2002 \text { (6), } 2003 \text { (4), } \\
2004 \text { (4), } 2005 \text { (3), } 2006 \text { (4), } \\
2007 \text { (1), } 2008 \text { (1), } 2009 \text { (4), } \\
2010 \text { (4), } 2013 \text { (2), } 2014 \text { (8) }\end{array}$ \\
\hline Curlew Sandpiper & $1,400^{*}$ & 8 & $\begin{array}{l}\text { December (3), January (1), } \\
\text { February (3), March (1) }\end{array}$ & $\begin{array}{l}1989 \text { (1), } 1993 \text { (1), } 1997 \text { (1), } \\
1998 \text { (2), } 2007 \text { (1), } 2008 \text { (1), } \\
2010 \text { (1) }\end{array}$ \\
\hline
\end{tabular}


Thornbill and Splendid Fairy-wren) that have declined significantly on the Swan Coastal Plain (Davis et al. 2013). Hence, the reserve is important for the conservation of many landbird species that are declining locally.

The importance of Lake McLarty was supported by two previous studies. During systematic surveys of 255 wetlands on Swan Coastal Plain between 1990 and 1992, more species were recorded (51) there than at any other wetland, which is over 10 more than any wetland of comparable or smaller size (Storey et al. 1993). It also had the fifth highest mean and maximum count of all wetlands surveyed, with a maximum count of 3,986 (Storey et al. 1993). Earlier surveys of wetlands in southwestern Australia between 1981 and 1985 concluded that Lake McLarty had the sixth highest number of species recorded (54) and all the wetlands where more species were recorded, except the estuarine Alfred Cove, were significantly larger than Lake McLarty (Jaensch et al. 1988). During that survey, Lake McLarty ranked 26th out of 197 wetlands in terms of highest total count of waterbirds (Jaensch et al. 1988). Furthermore, surveys for both these projects were conducted at regular intervals through the year, rather than targeting times of maximum waterbird richness and abundance. Surveys in the 1990s and 2000s (this study) revealed that Lake McLarty supported many more species and numbers of waterbirds than either of these surveys recorded. This probably resulted from better targeting of surveys for these times of maxima and, possibly, an increase in waterbird usage of Lake McLarty. Regardless, it is clear that Lake McLarty supports a very high richness and abundance of waterbirds, which regularly exceeds those of wetlands of comparable size, and is unarguably a very important wetland for the conservation of waterbirds both regionally and globally.

Waterbird usage of the lake varied with water depth with several species typically associated with either deep or shallow water. There were 40 complete waterbird counts conducted at water depths of $>600 \mathrm{~mm}$. At these depths, the fringing Melaleuca stands were flooded and species such as Freckled, Blue-billed and Musk Ducks, Hardhead, cormorants, grebes and Eastern Great Egret reached peak abundance. Overall numbers of birds were generally relatively low although the presence of large numbers of moulting Australian Shelduck on occasions lead to high overall numbers and nine dates at these depths had counts of $>10,000$. Species richness was moderate at these depths with $>35$ waterbird species recorded on six dates. There were 26 complete waterbird counts conducted at water depths between 300 and $600 \mathrm{~mm}$. At these depths, the water receded from the Melaleuca stands and there was an extensive shoreline of sedges and exposed mud. At these depths, species such as Pacific Black Duck, Eurasian Coot, Blackfronted Dotterel, Black-tailed Godwit, Marsh and Wood Sandpipers, Common Greenshank, Long-toed Stint, Silver Gull and Whiskered and White-winged Black Terns reached peak abundance. It was at these depths that waterbird richness reached its maxima, with five of the six most diverse counts being at these depths, and $>35$ waterbird species recorded on eight dates. Overall numbers of birds were moderate at these depths with counts of $>10,000$ birds on 12 dates, but numbers tended to increase as the lake got shallower with five of those counts recorded between depths of 300 and $360 \mathrm{~mm}$. There were 58 complete waterbird counts conducted at water depths below $300 \mathrm{~mm}$. At these depths, the shoreline started to consist of greater proportions of exposed mud and the lake was often shallow enough to permit short-legged species to forage across the entire lake. At these shallow depths, species such as Pink-eared Duck, Grey Teal, Banded Stilt, Red-necked Avocet, Red-necked Stint, Sharp-tailed and Curlew Sandpipers and Ruff reached their peak abundance. Although species richness was lowest at these depths, $>35$ waterbird species were recorded only once at these depths, this is when overall waterbird abundance was generally highest. At these depths, $>10,000$ individuals were recorded on 16 dates including eight out of the 11 highest counts.

Although systematic surveys have not occurred continuously over the past 35 years at Lake McLarty, there have been enough complete waterbird counts, supplemented by numerous observations, to indicate that the abundance of several species has changed over that period. There appear to have been eight species that have declined in abundance over that time: Eastern Great Egret, Purple Swamphen, Dusky Moorhen, Eurasian Coot, Red-kneed Dotterel, Wood Sandpiper, Long-toed Stint and Curlew Sandpiper. Of these species, it is likely that Wood Sandpiper and Long-toed Stint have declined along with the decline in emergent vegetation, primarily Typha and Juncus, at the lake over the past few decades (Figure 2). This decline in emergent vegetation occurred primarily up until the mid-1990s (Craig et al. 2001), which coincided with the declines of both these species, and continues to the present day. The decline of the Red-kneed Dotterel commenced in 1998 and the decline of the Purple Swamphen and Dusky Moorhen started in 2001. Given their habitat preferences elsewhere, it seems logical that their decline was related to the loss of emergent vegetation, however the decline started after most of the emergent vegetation was lost suggesting that other, unknown factors may have contributed to the declines of these species. The decline of Eastern Great Egret commenced around 1994 and for Eurasian Coot around 2008 but the reasons for these declines also remain unclear. Declines of the last species, Curlew Sandpiper, started around 2010, coinciding with significant global declines in this species, primarily associated with the destruction of stopover sites in north-eastern China and South Korea (Piersma et al. 2016). In contrast, only two species appear to have increased: Silver Gull, which was rare before 1995, and the Osprey which was not recorded before 2000. The gull has likely increased along with increasing anthropogenic modification across 
the Peel-Yalgorup area, which undoubtedly benefits this scavenger (Smith 1992). As Osprey records since 2000 probably refer to a single pair and their young, it is unlikely this reflects a population increase in the surrounding Peel-Yalgorup system. Instead it is more likely that this increase simply results from the fact that a pair either established their nest, or moved from a different location, at that time.

Although Lake McLarty supports an exceptionally diverse and abundant waterbird fauna, it unfortunately faces a number of significant threats that threaten its conservation value into the future. At least six factors have been hypothesised anecdotally to significantly influence waterbird numbers at Lake McLarty, both positively and negatively: (1) the opening of the Dawesville Cut; (2) the disappearance of emergent vegetation; (3) removal of cattle; (4) global wader population declines; (5) increased disturbance from Forrest Highway and residential subdivision; and (6) changes to the hydroperiod due to decreasing rainfall and associated terrestrialisation of the lakebed. The lack of systematic surveys at Lake McLarty over an extended period of time precludes us from conclusively establishing the effect of these factors on water numbers at Lake McLarty. However, an examination of data on peak waterbird numbers annually enables us to provide some evaluation of the influence of each of these factors on waterbird numbers at Lake McLarty over the period of the survey and make recommendations for future management of the lake with the caveat that, ideally, the effect of each of these factors should be investigated further. The opening of the nearby Dawesville Cut in August 1994 seems to have positively influenced waterbird numbers at Lake McLarty. The Dawesville Cut caused a $55 \%$ increase in tidal amplitude as well as increased salinity, in the adjacent Peel-Harvey Estuary (Bradby 1997; Gibson 2001) reducing the availability of mudflats to waterbirds. Our data show an increase in waterbirds and peak counts of internationally significant species at Lake McLarty after the cut was opened (Figure 2) suggesting some birds may have responded to the reduced availability of mudflats by moving to Lake McLarty. The loss of emergent vegetation on the lakebed also appears to have had a positive effect on waterbird populations. The lakebed was $80 \%$ covered in emergent vegetation (mostly Typha but also some Juncus) in the late 1970s (J. Lane, pers, comm.) that decreased to $\sim 30 \%$ by 1985 (MC, pers. obs.) and further to <5\% by 1995. The reasons for this decrease are unclear, but may have been due to increasing salinity (Muirden 2017). However, we show that this decrease in emergent vegetation coincided with a large increase in the peak numbers of waterbirds recorded on the lake (Figure 2). Given that waterbirds generally prefer to forage in open areas away from emergent vegetation (Niemuth et al. 2006; Pierce and Gawlik 2010), it seems likely that the loss of emergent vegetation exposed large expanses of open water and, at very shallow depths, large expanses of open mudflats for birds to forage upon and hence, a large increase in the number of waterbirds using the lake. The removal of cattle around 2001 has been postulated to have caused a decrease in waterbird numbers. This was based on the premise that reduced grazing meant that grass along the southern, and to a lesser extent the east, shore of the lake both grew in height and spread across previously bare mud reducing the habitat available for waterbirds, particularly waders. However, while the removal of cattle has likely reduced the quality of foraging habitat for some shorebird species at moderate water depths, our data do not indicate any strong effect of the removal of cattle on peak waterbird numbers and peak numbers of the species for which the lake is internationally important (Figure 2). In fact, the peak numbers of Grey Teal, Banded Stilt, Red-necked Stint and Sharp-tailed Sandpiper, as well as total waterbirds were all greater after the cattle were removed than before (Figure 2). The only species that showed a decline in abundance from 2001 were Purple Swamphen and Dusky Moorhen but, as neither of these species utilised the areas of grass and mud grazed by the cattle, it is difficult to ascribe their decline to the removal of cattle. We propose that cattle had negligible effect on peak waterbird numbers because when the water level was high enough to flood the grass grazed by cattle and provide suitable foraging habitat for waders within that grass, it was too deep (420 to $500 \mathrm{~mm}$ : Muirden 2017) for peak numbers of birds to be present (Table 2). Also, the relevant area where the cattle kept the grass short is only a few percent of the shoreline and lake area available to waterbirds. Additionally, some of the birds using the southern and south-eastern shoreline may have moved elsewhere on the lake and utilised different areas than when the cattle were present. The fact that cattle have grazed in the reserve since the 1880s (Department of Environment and Conservation 2008) and that waterbirds numbers have fluctuated greatly over that time further supports the idea that cattle grazing has not greatly influenced peak waterbird numbers at Lake McLarty. Increasing disturbance from the Forrest Highway and the residential development was proposed as a possible negative effect on waterbird numbers at Lake McLarty (Department of Environment and Conservation 2008). However, the anticipated increase in visitor numbers has not eventuated and may even have decreased because interest by birdwatchers has declined with reduced waterbird numbers. Another factor considered likely to have influenced waterbird numbers at Lake McLarty has been global declines in many populations of trans-equatorial migrants (Studds et al. 2017). This has not affected populations of most waterbird species at Lake McLarty as they are not transequatorial migrants, but it may have affected some species, including three species for which Lake McLarty is internationally important. There was little evidence global declines had influenced the numbers of Sharptailed Sandpiper at the lake. Despite significant declines of this species over the last four decades, which have been greatest in south-western Australia (Clemens et al. 2016), there was a near-record count $(5,500)$ in 2010 and 
3,000 were recorded in 2014 showing the lake remains internationally important for the species despite the declines. In contrast, global declines of Red-necked Stint may have influenced the abundance of this species at the lake. The global decline has been strongest since 2003 (Studds et al. 2017) and the decline at the lake started in 2005 with a strong decline since 2010 when the peak count has not exceeded 2300. Global declines may also have caused a decline in abundance of Curlew Sandpiper at the lake. Globally, this species has declined by $\sim 65 \%$ in the past 20 years (Studds et al. 2017) and is the species that has declined the most in Australia over the past four decades, with the strongest declines in southwestern Australia (Clemens et al. 2016). Although the abundance of Curlew Sandpiper at Lake McLarty remained high through much of the global decline with a peak count in 2007, numbers fell steeply from 2010, with no more than 120 recorded since. However, the sharp declines in these two species since 2010 coincided with the spread of herbaceous vegetation across the lakebed and this is likely to have been a more significant factor driving the declines at the lake. This suggests that Lake McLarty has provided high quality habitat for these species and continued to support high numbers until recently, despite the global population declines. The last factor considered to have influenced waterbird numbers at Lake McLarty is the change in the hydroperiod (the duration of inundation and drying) and our data indicate this factor has had the strongest influence on waterbird numbers along with the resultant process of terrestrialisation. A significant change in the hydroperiod occurred in 2006. Prior to 2006, the lake typically dried for between one and three months annually but, since that time, the lake has dried for between four and seven months annually (Muirden 2017). This is partly driven by declines in rainfall, with annual rainfall in the area being 11\% lower since 2000 than in the 30 years prior to that. However, the increase in drying period does not correlate exactly with the decline in rainfall suggesting additional factors are operating. The change in hydroperiod in 2006 coincides with the development of the residential subdivision, with 22 buildings having being constructed there. Since that time, the hydroperiod of the lake has not been tightly related to rainfall, suggested extraction of groundwater via bores may be an additional pressure (Muirden 2018). Current investigations are attempting to establish the relative influence of reduced rainfall and groundwater extractions on changes to the hydroperiod of the lake (P. Muirden, pers. comm.). The change in hydroperiod has significantly reduced the length of time the lake contains water, and hence, reduces the habitat quality for all waterbirds and the peak numbers of all birds and the seven species for which the lake is internationally important have all shown a consistent decline since 2006 (Figure 2). Migratory waders that use the lake have been disproportionately affected by the change in hydroperiod as the rich feeding habitats available as the lake dries are no longer available to the birds in February and March, when these species use such habitats for fattening up prior to northward migration (Craig et al. 2001). However, with the lake now usually drying in December or January, they are unable to do so under the present hydroperiod. Our data indicate that peak waterbird

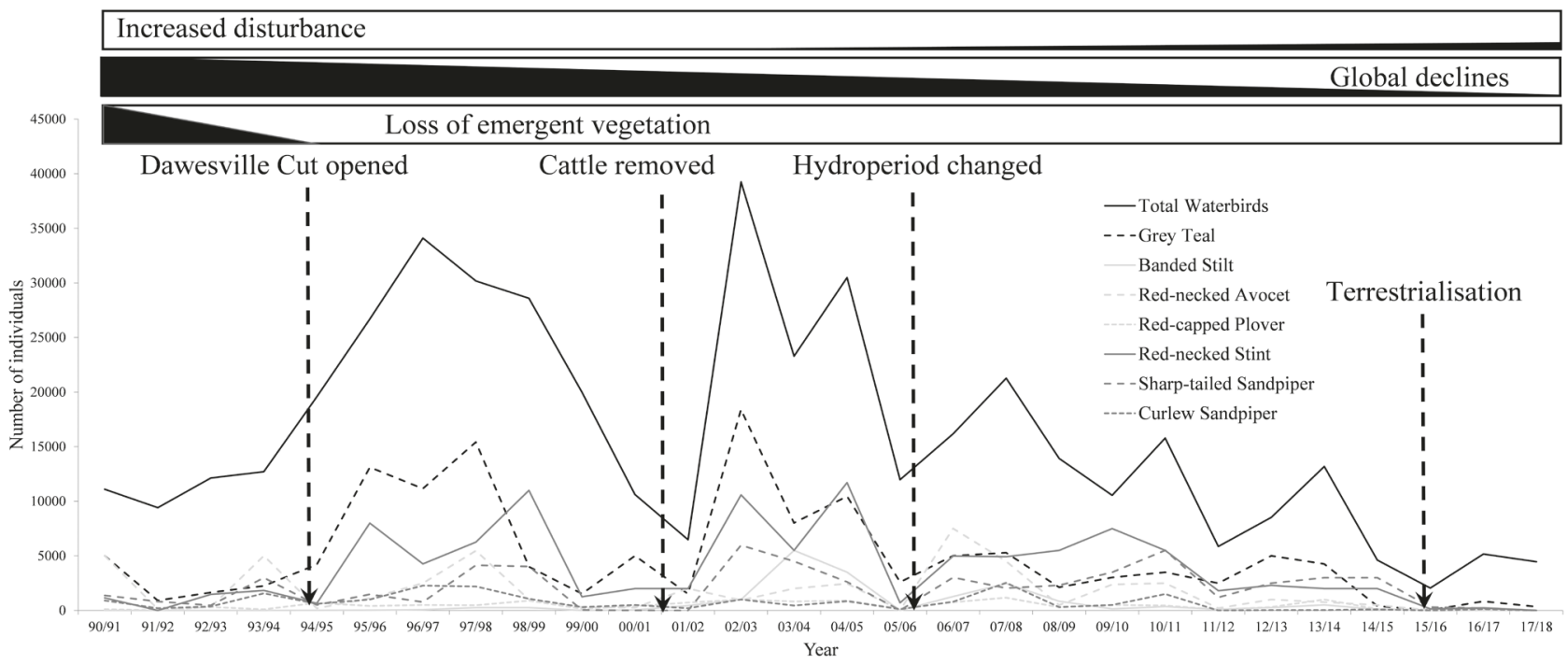

FIGURE 2

Graph showing the peak number of all waterbirds and the seven species for which Lake McLarty is internationally important, within each 12 month period from May to April, in relation to six factors hypothesised to have influenced waterbird numbers at Lake McLarty. The factors that happened as single events (Dawesville Cut opened, cattle removed, hydroperiod changed and subsequent terrestrialisation) are shown as dashed lines whereas factors that changed gradually over a period of time (increasing disturbance, global population declines of migratory waders and loss of emergent vegetation) are shown as shaded boxes above the graph. 

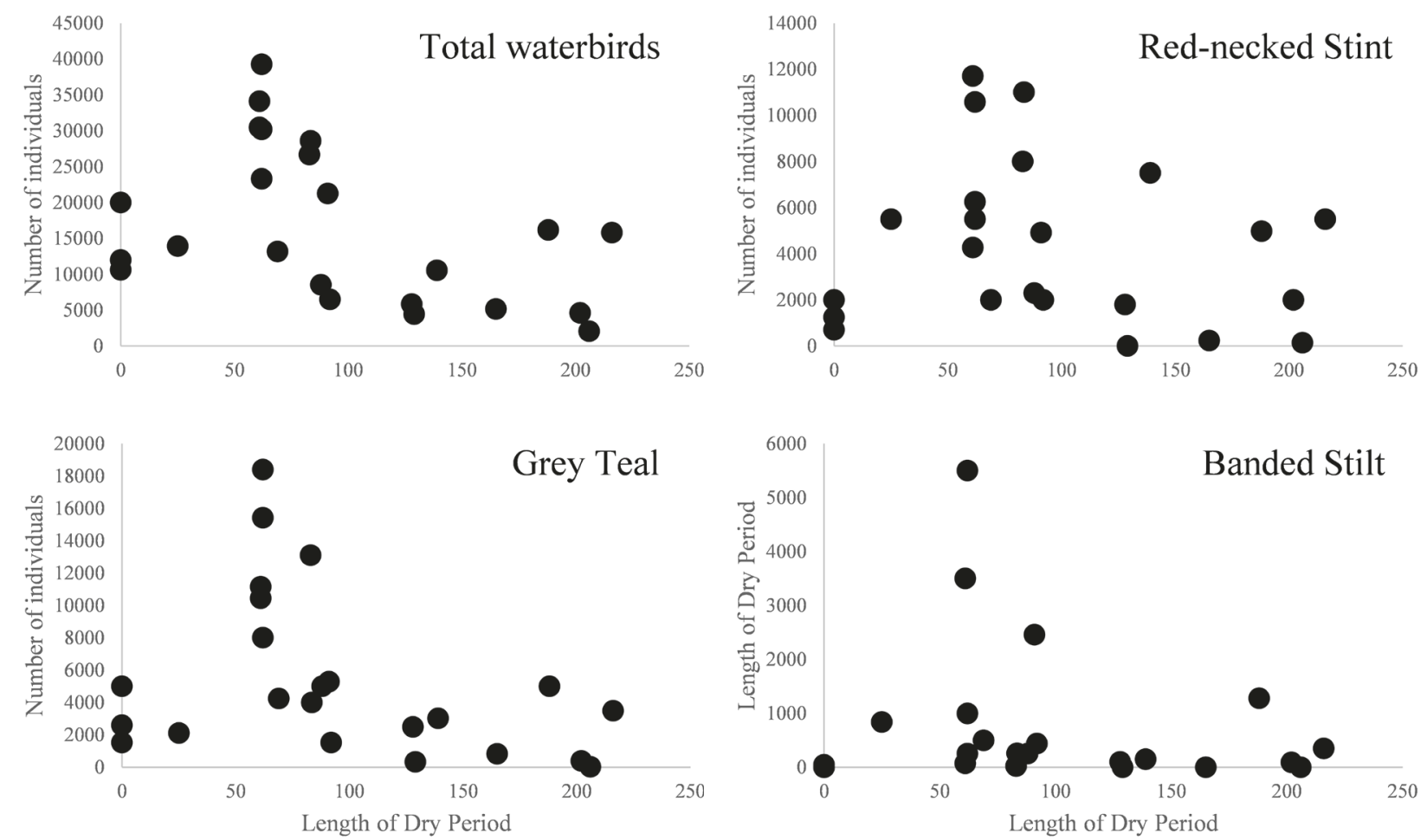

FIGURE 3 Graphs showing the peak number of all birds and a duck (Grey Teal), an Australian breeding wader (Banded Stilt) and a migratory wader (Red-necked Stint) in relation to the number of days between May and April that the lake is dry in each 12 month period. Note that numbers peak when the lake is dry for 2 to 3 months each year and numbers are much lower when the lake dries for longer or does not dry at all although the pattern is less marked for Red- necked Stints.

numbers, and peak numbers of those species for which the lake is internationally important, peaked when the lake was dry for 2 to 3 months a year and that peak numbers of waterbirds decline when the lake dries out for longer periods or does not dry out at all (Figure 3). The increased drying periods have also led to increases in the expression of acid sulphate soils (ASS). The extent of ASS has increased each year since first noted in 2015 (Muirden 2017). This has the potential to change the $\mathrm{pH}$ of lake water from alkaline $(\mathrm{pH} \sim 8-8.5)$ to acidic, which will likely significantly change the invertebrate community and in turn, the waterbird community. The increased drying period has also led to the colonisation of the lakebed by terrestrial vegetation, primarily grasses and samphire, a process known as terrestrialisation (Figure 4). This has greatly reduced the extent of exposed mudflats such that, currently, only $\sim 5 \%$ of the lakebed is exposed mud. This greatly reduces the feeding habitat for migratory waders and renders the lake poor quality habitat for these species. For example, during a survey on 27 December 2017 at a water level of $260 \mathrm{~mm}$, which historically was shallow enough to provide suitable conditions for a wide variety and abundance of waders, only four Common Greenshank and two Sharp-tailed Sandpiper were recorded. Future plans, through the Lake McLarty Recovery Team, are currently underway to investigate methods of diverting water from nearby drains into Lake McLarty with the aim of returning the lake to a pre-2006 hydroperiod when it dried for 2 to 3 months. It is hoped that doing so would also eliminate the significant dual threats of ASS and terrestrialisation.

In summary, Lake McLarty is a wetland of international importance that supports an extremely rich and abundant water bird community as well as globally significant population of seven waterbird species. However, recent counts indicate that the lake faces an uncertain future and may no longer consistently support internationally significant numbers of waterbirds. Declines in the abundance of some species is likely largely due to the disappearance of much of the emergent vegetation on the lake up until mid-1990s while global population declines may have been a further contributing factor for a few species. However, more recent changes in the hydroperiod of the lake and the associated issues of ASS and terrestrialisation threaten to significantly reduce the importance of the lake for all waterbird species. Plans to try and restore the hydroperiod of the lake to pre-2006 levels, where it dried for 2 to 3 months, are currently underway. It is hoped that the annotated list presented here will both showcase the conservation significance of Lake McLarty locally, nationally and globally, as well as provide an important baseline against which to assess the benefits of any future plans to restore the lake's conservation value and contribute to a more certain future for the lake and the species that utilise it. 

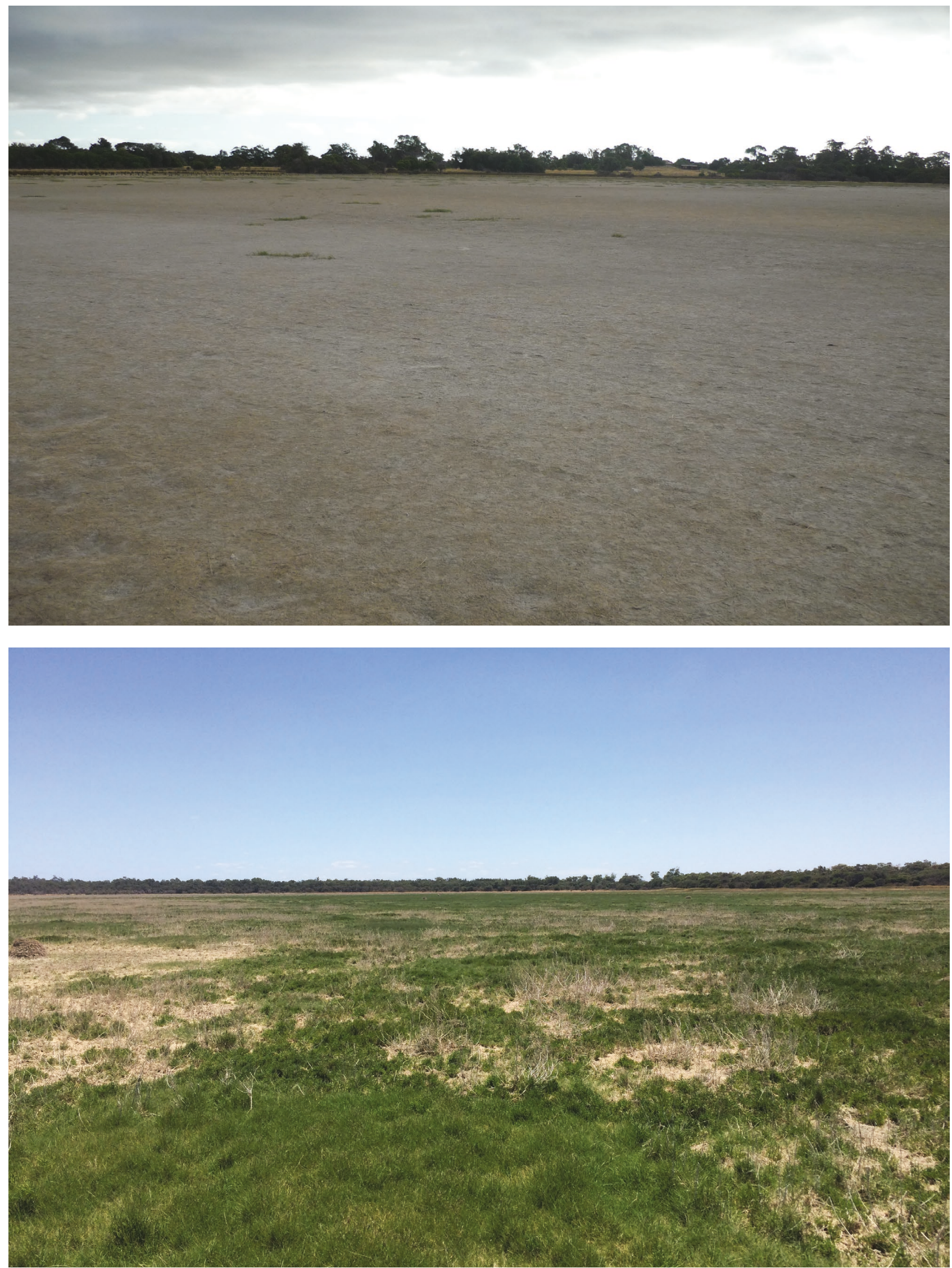

FIGURE $4 \quad$ Photographs showing increasing terrestrialisation of the lakebed due to changes in the hydroperiod of the lake. In February 2012 (top), the lakebed was comprised mostly of exposed silty mud providing excellent habitat for migratory and resident waders. In February 2018 (bottom), the lakebed had been colonised by grasses (Poaceae) and samphires (Chenopodiaceae) greatly reducing the area of exposed silty mud and, hence, the quality of the habitat for waders. 


\section{ACKNOWLEDGEMENTS}

We would like to thank the many observers who contributed their records to our database and eBird and to Geoff Barrett for supplying the top photograph in Figure 4. We thank Ron Johnstone and John Darnell for many fruitful discussions about Lake McLarty over many years and constructive comments on an earlier version of this manuscript.

\section{REFERENCES}

BirdLife International (2017). Waterbirds are showing widespread declines, particularly in Asia. http://datazone. birdlife.org/sowb/casestudy/waterbirds-are-showingwidespread-declines-particularly-in-asia.

BirdLife International (2018). Important Bird Areas factsheet: Lake McLarty. http://datazone.birdlife.org/site/factsheet/ lake-mclarty-iba-australia.

Blyth, J. and Watkins, D. (1992). Asian Dowitcher seen at Lake McLarty. Western Australian Bird Notes 63: 1.

Bradby, K. (1997). Peel-Harvey: The Decline and Rescue of an Ecosystem. Greening the Catchment Taskforce, Mandurah.

Burbidge, A. and Craig, M. (1996). Lake McLarty: An important Ramsar wetland. Western Australian Bird Notes 78: $10-13$.

Cai, W. and Cowan, T. (2006). SAM and regional rainfall in IPCC AR4 models: Can anthropogenic forcing account for southwest Western Australian winter rainfall reduction? Geophysical Research Letters 33: L24708.

Clemens, R.S., Rogers, D.I., Hansen, B.D., Gosbell, K., Minton, C.D.T., Straw, P., Bamford, M., Woehler, E.J., Milton, D.A., Weston, M.A., Venables, B., Wellet, D., Hassell, C., Rutherford, B., Onton, K., Herrod, A., Studds, C.E., Choi, C-Y., Dhanjal-Adams, K.L., Murray, N.J., Skilleter, G.A. and Fuller, R.A. (2016). Continental-scale decreases in shorebird populations in Australia. Ети 116: 119-135.

Craig, M., Darnell, J., Davis, C., Kirkby, T. and Singor, M. (2001). Waders at Lake McLarty, Western Australia. The Stilt 38: 18-32.

Darnell, J. (1997). Northern Shoveler (Anas clypeata) at Lake McLarty. Western Australian Bird Notes 84: 1-2

Davis, R.A., Gole, C. and Roberts, J.D. (2013). Impacts of urbanisation on the native avifauna of Perth, Western Australia. Urban Ecosystems 16: 427-452.

Department of Environment and Conservation (2008). Lake McLarty Nature Reserve 2008: Management Plan Number 60. Department of Environment and Conservation, Kensington.

Dudgeon, D., Arthington, A.H., Gessner, M.O., Kawabata, Z.I., Knowler, D.J., Lévêque, C., Naiman, R.J., PrieurRichard, A.H., Soto, D., Stiassny, L.J. and Sullivan, C.A. (2006). Freshwater biodiversity: importance, threats, status and conservation challenges. Biological Reviews of the Cambridge Philosophical Society 81: 163-182.

Environment Australia (2001). A Directory of Important Wetlands in Australia, Third Edition. Environment Australia, Canberra.

Gibson, N. (2001). Decline of the riverine trees of the Harvey River delta following the opening of the Dawesville Channel. Journal of the Royal Society of Western Australia 84: 116-117.

Higgins, P.J. and Davies, S.J.J.F. (eds.) (1996). Handbook of Australian, New Zealand \& Antarctic birds: Volume 3, Snipe to pigeons. Oxford University Press, Melbourne.
Holland, R.A., Darwall, W.R.T. and Smith, K.G. (2012). Conservation priorities for freshwater biodiversity: the Key Biodiversity Area approach refined and tested for continental Africa. Biological Conservation 148: 167-179.

Jaensch, R.P., Vervest, R.M. and Hewish, M.J. (1988). Waterbirds in Nature Reserves of South-Western Australia 1981-1985: Reserve Accounts. RAOU Report No. 30. Royal Australasian Ornithologists Union, Melbourne.

Johnstone, R.E. and Darnell, J.C. (2018). Checklist of the Birds of Western Australia. http://museum.wa.gov.au/sites/default/ files/Checklist $\% 20$ of $\% 20$ Birds $\% 20$ of $\% 20 \mathrm{WA} \% 20-\% 20$ April\%202018_0.pdf.

Johnstone, R.E. and Storr, G.M. (2001). Handbook of Western Australian birds: Volume 1, Non-passerines (Emu to Dollarbird). Western Australian Museum, Perth.

Lane, B.A. and Davies, J.N. (1987). Shorebirds in Australia. Nelson, Melbourne.

Laurance, W.F., Sayer, J. and Cassman, K.G. (2014). Agricultural expansion and its impacts on tropical nature. Trends in Ecology and Evolution 29: 107-116.

Muirden, P. (2017). Lake McLarty Hydrology Review: June 2017. Report to the Department of Environment and Conservation, Unpublished.

Muirden, P. (2018). Lake McLarty Hydrology 2017: April 2018. Report to the Department of Biodiversity, Conservation and Attractions. Unpublished.

Niemuth, N.D., Estey, M.E., Reynolds, R.E., Loesch, C.R. and Weeks, W.A. (2006). Use of wetlands by spring-migrant shorebirds in agricultural landscapes of North Dakota's Drift Prairie. Wetlands 26: 30-39.

Pierce, R.L. and Gawlik, D.E. (2010). Wading bird foraging habitat selection in the Florida Everglades. Waterbirds 33: 494-503.

Piersma, T., Lok, T., Chen, Y., Hassell, C.J., Yang, H.Y., Boyle, A., Slaymaker, M., Chan, Y.C., Melville, D.S. Zhang, Z.W. and Ma, Z. (2016). Simultaneous declines in summer survival of three shorebird species signals a flyway at risk. Journal of Applied Ecology 53: 479-490.

Ramsar (2018). The Ramsar Sites Criteria. https://www.ramsar. org/sites/default/files/documents/library/ramsarsites criteria_eng.pdf

Ramsar Sites Information Service (2018). Peel-Yalgorup system. https://rsis.ramsar.org/ris/482

Smith, G.C. (1992). Silver gulls and emerging problems from increasing abundance. Corella 16: 39-46.

Storr, G.M. and Johnstone, R.E. (1988). Birds of the Swan Coastal Plain and adjacent seas and islands. Records of the Western Australian Museum Supplement 28.

Storey, A.W., Vervest, R.M., Pearson, G.B. and Halse, S.A. (1993). Wetlands of the Swan Coastal Plain. Volume 7: Waterbird usage of wetlands in the Swan Coastal Plain. Water Authority of Western Australia, Perth, Western Australia.

Strayer, D.L. and Dudgeon, D. (2010). Freshwater biodiversity conservation: recent progress and future challenges. Journal of the North American Benthological Society 29: 344-358.

Studds, C.E., Kendall, B.E., Murray, N.J., Wilson, H.B., Rogers, D.I., Clemens, R.S., Gosbell, K., Hassell, C.J., Jessop, R., Melville, D.S., Milton, D.A., Minton, C.D.T., Possingham, H.P., Riegen, A.C., Straw, P., Woehler, E.J. and Fuller, R.A. (2017). Rapid population decline in migratory shorebirds relying on Yellow Sea tidal mudflats as stopover sites. Nature Communications 8: 14895.

MANUSCRIPT RECEIVED 7 JUNE 2018; ACCEPTED 15 NOVEMBER 2018. 